\title{
TOMO-ETNA experiment at Etna volcano: activities on land
}

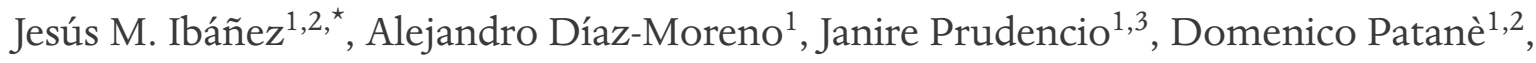
Luciano Zuccarello ${ }^{2}$, Ornella Cocina ${ }^{2}$, Birger-Gottfried Lühr ${ }^{4}$, Francisco Carrión ${ }^{1}$, Mauro Coltelli ${ }^{2}$, Pier Paolo G. Bruno ${ }^{5}$, Francesca Bianco ${ }^{6}$, Margaret Hellweg ${ }^{7}$, Rafael Abreu ${ }^{1}$, Gerardo Alguacil $^{1}$, Isaac Álvarez ${ }^{8}$, Carolina Aranda ${ }^{1}$, Carmen Benítez ${ }^{8}$, Luisa Buontempo ${ }^{1}$, Mercedes Feriche $^{1}$, Luz García ${ }^{8}$, Daniel García-Quiroga ${ }^{1}$, José B. Martín ${ }^{1}$, José Morales ${ }^{1}$, Inmaculada Serrano ${ }^{1}$, Manuel Titos ${ }^{8}$, Lucia Urbano ${ }^{1}$, Gianpiero Aiesi ${ }^{2}$, Raffaele Azzaro ${ }^{2}$, Graziella Barberi $^{2}$, Massimo Cantarero ${ }^{2}$, Pasqualino Cappuccio ${ }^{2}$, Danilo Cavallaro ${ }^{2,9}$, Danilo Contrafatto ${ }^{2}$, Sergio Di Prima ${ }^{2}$, Susanna Falsaperla ${ }^{2}$, Marco Firetto Carlino ${ }^{2}$, Elisabetta Giampiccolo ${ }^{2}$, Graziano Larocca ${ }^{2}$, Carla Musumeci ${ }^{2}$, Mario Paratore ${ }^{2}$, Daniele Pellegrino ${ }^{2}$, Mario Pulvirenti ${ }^{2}$, Salvatore Rapisarda ${ }^{2}$, Marco Sassano $^{2}$, Luciano Scarfi ${ }^{2}$, Luciano Scuderi ${ }^{2}$, Antonino Sicali ${ }^{2}$, Giuseppina Tusa ${ }^{2}$, Tiziana Tuvè ${ }^{2}$, Edoardo Del Pezzo ${ }^{1,6}$, Stefano Fiore ${ }^{6}$, Danilo Galluzzo ${ }^{6}$, Mario La Rocca ${ }^{6}$, Mariantonietta Longobardi ${ }^{6}$, Luciano Nocerino $^{6}$, Solange Scognamiglio ${ }^{6}$, Carla Bottari ${ }^{10}$, Fabio Criscuoli ${ }^{11}$, Pasquale De Gori ${ }^{11}$, Lucian Giovani ${ }^{11}$, Alfio Messina ${ }^{10}$, Marcello Silvestri ${ }^{11}$, Simone Salimbeni ${ }^{12}$, Torsten Dahm ${ }^{4}$, Araceli García-Yeguas ${ }^{1,13}$, Alfonso Ontiveros ${ }^{1,14}$, Enrique Coello ${ }^{15}$, María Cordero ${ }^{15}$, Cayetano Guillén ${ }^{15}$, M. Carmen Romero ${ }^{15}$, Hannah McCann ${ }^{16}$, Mauricio Bretón ${ }^{17}$, Sierra Boyd ${ }^{7}$, Ivan Koulakov ${ }^{18,19}$, Sergey Abramenkov ${ }^{18}$

${ }^{1}$ Instituto Andaluz de Geofisica, Universidad de Granada, Granada, Spain

${ }^{2}$ Istituto Nazionale di Geofisica e Vulcanologia, Sezione di Catania, Osservatorio Etneo, Catania, Italy

${ }^{3}$ University of California, Department of Earth and Planetary Sciences, Berkeley, USA

${ }^{4}$ Helmholtz-Zentrum Potsdam, Deutsches GeoForschungsZentrum GFZ, Potsdam, Germany

${ }^{5}$ Petroleum Institute, Department of Petroleum Geosciences, Abu Dhabi, United Arab Emirates

${ }^{6}$ Istituto Nazionale di Geofisica e Vulcanologia, Sezione di Napoli, Osservatorio Vesuviano, Naples, Italy

${ }^{7}$ University of California, Berkeley Seismological Laboratory, Berkeley, USA

${ }^{8}$ Universidad de Granada, Departamento de Teoría de la Señal Telemática y Comunicaciones, Granada, Spain

${ }^{9}$ Università di Catania, Dipartimento di Scienze Biologiche, Geologiche e Ambientali, Catania, Italy

${ }^{10}$ Istituto Nazionale di Geofisica e Vulcanologia, Sezione Roma 2, Rome, Italy

${ }^{11}$ Istituto Nazionale di Geofisica e Vulcanologia, Centro Nazionale Terremoti, Rome, Italy

${ }^{12}$ Istituto Nazionale di Geofisica e Vulcanologia, Sezione di Bologna, Bologna, Italy

${ }^{13}$ Universidad de Cádiz, Departamento de Física Aplicada, Cádiz, Spain

${ }^{14}$ Universidad de Jaén, Jaén, Spain

${ }^{15}$ Universidad de La Laguna, Tenerife, Spain

${ }^{16}$ University College of Dublin, Dublin, Ireland

${ }^{17}$ Universidad de Colima, Observatorio Volcanológico, Colima, Mexico

${ }^{18}$ IPGG SB RAS, Novosibirsk, Russia

${ }^{19}$ Novosibirsk State University, Novosibirsk, Russia

\section{Article history}

Received January 14, 2016; accepted March 9, 2016.

Subject classification: Active and passive seismic experiment, Seismic tomography, Etna volcano, Seismic instruments, Oceanographic vessels, Active volcanoes. 


\section{ABSTRACT}

In the present paper we describe the on-land field operations integrated in the TOMO-ETNA experiment carried out in June-November 2014 at Mt. Etna volcano and surrounding areas. This terrestrial campaign consists in the deployment of 90 short-period portable three-component seismic stations, 17 broadband seismometers and the coordination with 133 permanent seismic station belonging to Italy's Istituto Nazionale di Geofisica e Vulcanologia (INGV). This temporary seismic network recorded active and passive seismic sources. Active seismic sources were generated by an array of air-guns mounted in the Spanish oceanographic vessel "Sarmiento de Gamboa" with a power capacity of up to 5200 cubic inches. In total more than 26,000 shots were fired and more than 450 local and regional earthquakes were recorded. We describe the whole technical procedure followed to guarantee the success of this complex seismic experiment. We started with the description of the location of the potential safety places to deploy the portable network and the products derived from this search (a large document including full characterization of the sites, owners and indication of how to arrive to them). A full technical description of the seismometers and seismic sources is presented. We show how the portable seismic network was deployed, maintained and recovered in different stages. The large international collaboration of this experiment is reflected in the participation of more than 75 researchers, technicians and students from different institutions and countries in the on-land activities. The main objectives of the experiment were achieved with great success.

\section{Introduction. The importance of an active seismic tomography in Etna volcano}

Mt. Etna is one of the most fascinating natural laboratories for studying the deep structure of an active volcano with seismic tomography. Mt. Etna's eruptive dynamics are the result of a complex interaction between magma in its plumbing system, the regional (deep crust) tectonic regime, and local (shallow crust; volcanic edifice) structures, partially controlled by flank instability. Magma ascent driving conditions (e.g., structural setting, tectonic forces) are not yet completely understood. One of the main limitations in understanding the volcano's eruptive dynamics is the insufficient knowledge of its intermediate and deep crust. As indicated in Ibáñez et al. [2016, in this volume] in the last 25 years, several seismic and tomographic experiments have been focused on the study of Mt. Etna's structure using different techniques and data sets. The TOMO-ETNA experiment is an international and multi-institutional joint effort focused into providing answers to some of the open questions associated to the structure and dynamics of Mt. Etna. This experiment will take advantage of the use of both active and passive seismic sources and the combination of information of other seismic and geophysics measurements such as marine seismic reflection [Coltelli et al. 2016, in this volume; Firetto Carlino et al. 2016, in this volume] or magnetic profiles
[Cavallaro et al. 2016, in this volume].

A tomography image involves a great amount of seismic data [Lees 2007] recorded by a dense seismic network, a requisite often difficult to achieve in a reasonable time interval due to an absence of seismicity or the lack of stable and dense seismic networks [e.g Chouet 1996, 2003; Chouet and Matoza 2013; McNutt 2002, 2005; Wassermann 2002; Zobin 2011]. This problem can be solved by planning active seismic experiments such as we will summarize in this section. Following Koulakov and Shapiro [2015], it is possible to use different seismic sources that they divided into three categories: human-made sources, earthquakes, and ambient seismic noise. Fully controlled artificial sources are expected to provide the highest accuracy of tomographic images. At the same time, their implementation on volcanoes is very sophisticated and expensive. Another shortcoming of artificial sources is that they cannot be produced at depth. In regions with welldistributed volcano-tectonic seismicity, earthquakes may give a distribution of sources plausible for highresolution seismic tomography. However, many volcanoes do not generate relevant seismicity. Human-made seismic sources include explosions, vibrators, air-gun shots, and weight (or mass) drops and are usually called active sources. There are some onshore experiments which use chemical explosions of sufficiently large magnitude to generate seismic signals propagating to distances of dozens kilometers and depths of a few kilometers. The problem of such explosions is that they are fairly expensive and thus their number is strongly limited. Furthermore, chemical explosions are not ecologically sustainable and they are prohibited in most volcanic areas [Koulakov and Shapiro 2015]. An alternative method of active-source onshore generation might be using vibrators which are more ecologically safe compared to explosions. However, for the purposes of volcano tomography, the vibrators should be sufficiently powerful and heavy to enable the required propagation of seismic rays. In reality, the transportation of powerful vibrators appears to be not possible in most volcanic areas; therefore, they are not widely used in practice. Again following Koulakov and Shaphiro [2015], in case a volcano is located close to the seashore, it is possible to use underwater air-guns as sources of seismic signal. The advantage is that air-gun shots are rather cheap and sufficiently powerful. They can be frequently generated along the ship cruise that gives a huge data base with a clear technology of processing. The problem is that these sources are limited by the shore line and not suitable for most volcanoes. The major advantage of the active sources is that their parameters are known. The problem is that they are lo- 
cated close to the surface, and seismic signals propagate along the nearly horizontal ray paths. Another problem, which is mostly observed for the air-gun shots, is that they generate very weak $S$ waves which cannot be picked and used for tomography studies.

In the last 20 years the number of dedicated experiments using active seismic sources has been increasing. In order to give a real dimension of the nature of the TOMO-ETNA experiment we will present, in Table 1, a short revision of some of the most important experiment carried out in active volcanoes around the word. In Figure 1 we plot the position of the volcanoes described in the Table 1.

The TOMO-ETNA active seismic experiment is probably one of the most complex experiments performed in an active volcano to obtain a seismic tomography. Ibáñez et al. [2016, in this volume] provide a full description of the objectives, plans and involved research projects associated to this experiment. In order to solve some of the problems associated to the exclusive use of active sources this experiment was designed using both active and passive seismic sources. Passive sources (earthquakes) were selected for the period in which the active seismic survey was performed (JuneJuly 2014) in order to produce a real snapshot of the Mt. Etna structure and to avoid potential influences of structural evolution with time, following the observations done previously by Barberi et al. [2016, in this

\begin{tabular}{|c|c|c|c|c|c|c|c|c|c|}
\hline & Region & $\begin{array}{l}\text { Active } \\
\text { source }\end{array}$ & $\begin{array}{c}\text { No. of } \\
\text { sources }\end{array}$ & $\begin{array}{c}\text { No. of } \\
\text { stations }\end{array}$ & $\begin{array}{l}\text { Station } \\
\text { type }\end{array}$ & Year & P-phases & Area & Reference \\
\hline \multirow[t]{5}{*}{ Japan } & Kirishima & $\begin{array}{l}\text { Chemical } \\
\text { explosions }\end{array}$ & $\begin{array}{l}6(200- \\
250 \mathrm{~kg})\end{array}$ & 163 & & 1994 & & & $\begin{array}{l}\text { Tomatsu et al. } \\
\text { [2001] }\end{array}$ \\
\hline & Bandai & $\begin{array}{l}\text { Chemical } \\
\text { explosions }\end{array}$ & $\begin{array}{l}8(200- \\
250 \mathrm{~kg})\end{array}$ & 298 & $\begin{array}{l}\text { 1-component } \\
\text { short-period } \\
\text { seimometers }\end{array}$ & 1997 & 2200 & $25 \times 20 \mathrm{~km}$ & $\begin{array}{c}\text { Yamawaki et al. } \\
{[2004]}\end{array}$ \\
\hline & Asama & $\begin{array}{l}\text { Chemical } \\
\text { explosions }\end{array}$ & $\begin{array}{l}5(200- \\
300 \mathrm{~kg})\end{array}$ & 464 & $\begin{array}{l}\text { 1-component } \\
2 \mathrm{~Hz} \\
\text { Mark L-22D } \\
\text { seismometer }\end{array}$ & 2006 & $>2000$ & & $\begin{array}{l}\text { Aoki et al. [2009]; } \\
\text { Yamamoto and Sato } \\
{[2010]}\end{array}$ \\
\hline & Usu & $\begin{array}{l}\text { Chemical } \\
\text { explosions }\end{array}$ & $\begin{array}{l}7(200- \\
250 \mathrm{~kg})\end{array}$ & 288 & $\begin{array}{l}\text { 1-component } \\
2 \mathrm{~Hz} \\
\text { seismometer }\end{array}$ & 2001 & & & $\begin{array}{c}\text { Onizawa et al. } \\
{[2007]}\end{array}$ \\
\hline & Iwate & $\begin{array}{l}\text { Chemical } \\
\text { explosions }\end{array}$ & $\begin{array}{l}6(200- \\
250 \mathrm{~kg})\end{array}$ & 330 & $\begin{array}{l}\text { 1-component } \\
2 \mathrm{~Hz} \\
\text { seismometer }\end{array}$ & $\begin{array}{l}1998- \\
2003\end{array}$ & 2676 & $30 \times 10 \mathrm{~m}$ & $\begin{array}{l}\text { Nishimura et al. } \\
\quad[2000,2005] ; \\
\text { Tanaka et al. }[2002]\end{array}$ \\
\hline \multirow[t]{4}{*}{ Italy } & $\begin{array}{c}\text { Vesuvius } \\
\text { and } \\
\text { Campi Flegrei }\end{array}$ & $\begin{array}{l}\text { Chemical } \\
\text { explosions }\end{array}$ & $\begin{array}{l}20(200- \\
800 \mathrm{~kg})\end{array}$ & 140 & $\begin{array}{c}\text { Most } \\
\text { 3-component } \\
\text { digital } \\
\text { seismometers }\end{array}$ & 1994 & & $\begin{array}{l}25 \text { to } 40 \mathrm{~km} \\
\text { long profiles. } \\
\text { Only } \\
\text { at Vesuvius. }\end{array}$ & $\begin{array}{c}\text { Zollo et al. } \\
\text { [1996, 1998, 2002]; } \\
\text { Gasparini [1998]; } \\
\text { Di Stefano and } \\
\text { Chiarabba [2002] }\end{array}$ \\
\hline & & Air-gun & $\begin{array}{l}5000 \\
\text { shots }\end{array}$ & 134 & $\begin{array}{c}\text { OBSs and } \\
\text { 3-component } \\
\text { digital } \\
\text { seismometers }\end{array}$ & 2001 & & $\begin{array}{c}\text { Vesuvius } \\
\text { and } \\
\text { Campi Flegrei } \\
\text { caldera }\end{array}$ & $\begin{array}{l}\text { Zollo et al. [2003]; } \\
\text { Judenherc and } \\
\text { Zollo [2004]; } \\
\text { Vanorio et al. [2005]; } \\
\text { Battaglia et al. [2008]; } \\
\text { De Siena et al. [2010, } \\
\text { 2011] }\end{array}$ \\
\hline & Stromboli & Air-gun & $\begin{array}{l}>1500 \\
\text { shots }\end{array}$ & 43 & $\begin{array}{c}\text { OBSs and } \\
\text { 3-component } \\
\text { digital } \\
\text { seismometers }\end{array}$ & 2006 & & & $\begin{array}{c}\text { Marsella et al. [2007]; } \\
\text { Castellano et al. [2008]; } \\
\text { Prudencio et al. } \\
\text { [2015c] }\end{array}$ \\
\hline & Mt. Etna & $\begin{array}{l}\text { Chemical } \\
\text { explosions }\end{array}$ & & & & 1968 & & & Cassinis et al. [1969]. \\
\hline
\end{tabular}

Table 1. Brief summary of the most important active seismic experiment performed over the world during the las 20 years. (Table continues on next page). 


\begin{tabular}{|c|c|c|c|c|c|c|c|c|c|}
\hline \multicolumn{2}{|c|}{ Region } & $\begin{array}{l}\text { Active } \\
\text { source }\end{array}$ & $\begin{array}{c}\text { No. of } \\
\text { sources }\end{array}$ & $\begin{array}{c}\text { No. of } \\
\text { stations }\end{array}$ & $\begin{array}{c}\text { Station } \\
\text { type }\end{array}$ & Year & P-phases & Area & Reference \\
\hline & & $\begin{array}{l}\text { Chemical } \\
\text { explosions }\end{array}$ & & & & 1977 & & & Colombi et al. [1979] \\
\hline & & Air-gun & & & & 1992 & & & $\begin{array}{c}\text { Hirn et al. [1997]; } \\
\text { Nicolich et al. [2000] }\end{array}$ \\
\hline Indonesia & Merapi & Air-gun & $\begin{array}{c}1 \text { shot } \\
\text { every } 2 \text { min }\end{array}$ & 75 & $\begin{array}{l}\text { Short-period } \\
\text { seismometers }\end{array}$ & $\begin{array}{l}1997- \\
1998\end{array}$ & $>2500$ & $\begin{array}{c}3 \text { seismic } \\
\text { profiles } \\
\text { with a total of } \\
4.6 \mathrm{~km} \text { long }\end{array}$ & $\begin{array}{c}\text { Zschau and } \\
\text { Westerhaus (1998]; } \\
\text { Wegler et al. [1999]; } \\
\text { Wegler and Lühr } \\
\text { [2001]; Maercklin } \\
\text { et al. [2000] }\end{array}$ \\
\hline \multirow[t]{2}{*}{ Antartica } & $\begin{array}{l}\text { Deception } \\
\text { Island }\end{array}$ & Air-gun & $\begin{array}{l}>6600 \\
\text { shots }\end{array}$ & 109 & $\begin{array}{c}\text { OBSs and } \\
\text { 3-component } \\
\text { digital } \\
\text { seismometers }\end{array}$ & 2005 & & $25 \times 25 \mathrm{~km}$ & $\begin{array}{l}\text { Barclay et al. [2009]; } \\
\text { Ben-Zvi et al. (2009]; } \\
\text { Zandomeneghi et al. } \\
\text { [2009]; García-Yeguas } \\
\text { et al. [2011]; Carmona } \\
\text { et al. [2012]; Prudencio } \\
\text { et al. [2013a, 2015a] }\end{array}$ \\
\hline & Mt. Erebus & $\begin{array}{l}\text { Chemical } \\
\text { explosions }\end{array}$ & 12 & 91 & Seismometers & $\begin{array}{l}2008- \\
2009\end{array}$ & & $4 \times 4 \mathrm{~km}$ & $\begin{array}{l}\text { Zandomeneghi et al. } \\
\qquad[2010,2013]\end{array}$ \\
\hline Spain & $\begin{array}{l}\text { Tenerife } \\
\text { Island }\end{array}$ & Air-gun & $\begin{array}{l}6850 \\
\text { shots }\end{array}$ & 137 & $\begin{array}{l}\text { 3-component } \\
\text { digital } \\
\text { seismometers }\end{array}$ & 2007 & $>120,000$ & & $\begin{array}{c}\text { Ibáñez et a. [2008]; } \\
\text { De Barros et al. [2012]; } \\
\text { García-Yeguas et al. } \\
\text { (2012]; Lodge et al. } \\
\text { [2012]; Prudencio et al. } \\
\text { [2013b, 2015b] }\end{array}$ \\
\hline Caribbean Sea & $\begin{array}{l}\text { Monserrat } \\
\text { Island }\end{array}$ & Air-gun & $\begin{array}{l}4413 \\
\text { shots }\end{array}$ & 248 & $\begin{array}{c}\text { OBSs and } \\
\text { 3-component } \\
\text { digital } \\
\text { seismometers }\end{array}$ & 2007 & 115,000 & & $\begin{array}{l}\text { Paulatto et al. [2010]; } \\
\text { Shalev et al. [2010]; } \\
\text { Voight et al. [2014] }\end{array}$ \\
\hline New Zealand & Tongariro & $\begin{array}{c}\text { Drop } \\
\text { of masses }\end{array}$ & $\begin{array}{c}11 \\
\text { masses }\end{array}$ & 4 & Seismometers & 2012 & & & Jolly et al. [2014] \\
\hline USA & Mt. St. Helens & $\begin{array}{l}\text { Chemical } \\
\text { explosions }\end{array}$ & $\begin{array}{c}35(454 \\
\text { or } 908 \mathrm{~kg})\end{array}$ & 3500 & $\begin{array}{l}\text { Short-period } \\
\text { seismometers }\end{array}$ & 2014 & & $80 \times 80 \mathrm{~km}$ & $\begin{array}{l}\text { Kiser et al. [2013]; } \\
\text { Levandier et al. [2015] }\end{array}$ \\
\hline
\end{tabular}

Table 1 (continues from previous page). Brief summary of the most important active seismic experiment performed over the world during the las 20 years.

volume]. In the present manuscript we describe all activities developed to carry out the necessary activities to work on land, from the search of sites to the recovery of equipment and data.

\section{Seismic instruments and networks}

\subsection{On-land portable short-period seismic stations}

On-land portable seismic stations were provided by the Geophysical Instrument Pool Potsdam (GIPP), Germany [Ibáñez et al. 2016, in this volume]. They are composed of a DATA-CUBE3 recorder and triaxial seismometers PE-6/ B 4.5 Hz or Mark L-4C-3D. In Figure 2 we show pictures of these types of seismic stations. The data logger is a three-channel recorder (Figure 2a) with sampling rate of 100 samples per second. Its main characteristics are a selectable gain $\times 1$ to $\times 32$ full scale input of $4.1 \mathrm{Vpp}$ and gain 1 and sample rate up to 400 sps ( 3 channels), and an effective resolution typically of 21.5 bit and 100 sps. Tables 2 and 3 show some important parameters of the acquisition systems and the seismic sensors such as the sensitivity and clip values. The GPS of the station is integrated on the top of the Cube data logger and has an accuracy of $<10$ ms over 20 days without processing or $<0.01 \mathrm{~ms}$ with processing. These stations were powered with $2 \mathrm{D}$ cells batteries with an average duration of 14 days. The sensor is composed of one vertical component SM-6/U-B 4.5 Hz geophone and two horizontal component SM-6/H-B $4.5 \mathrm{~Hz}$ geophones (Figure $2 \mathrm{~b}$ ). The flat response of the sensor 


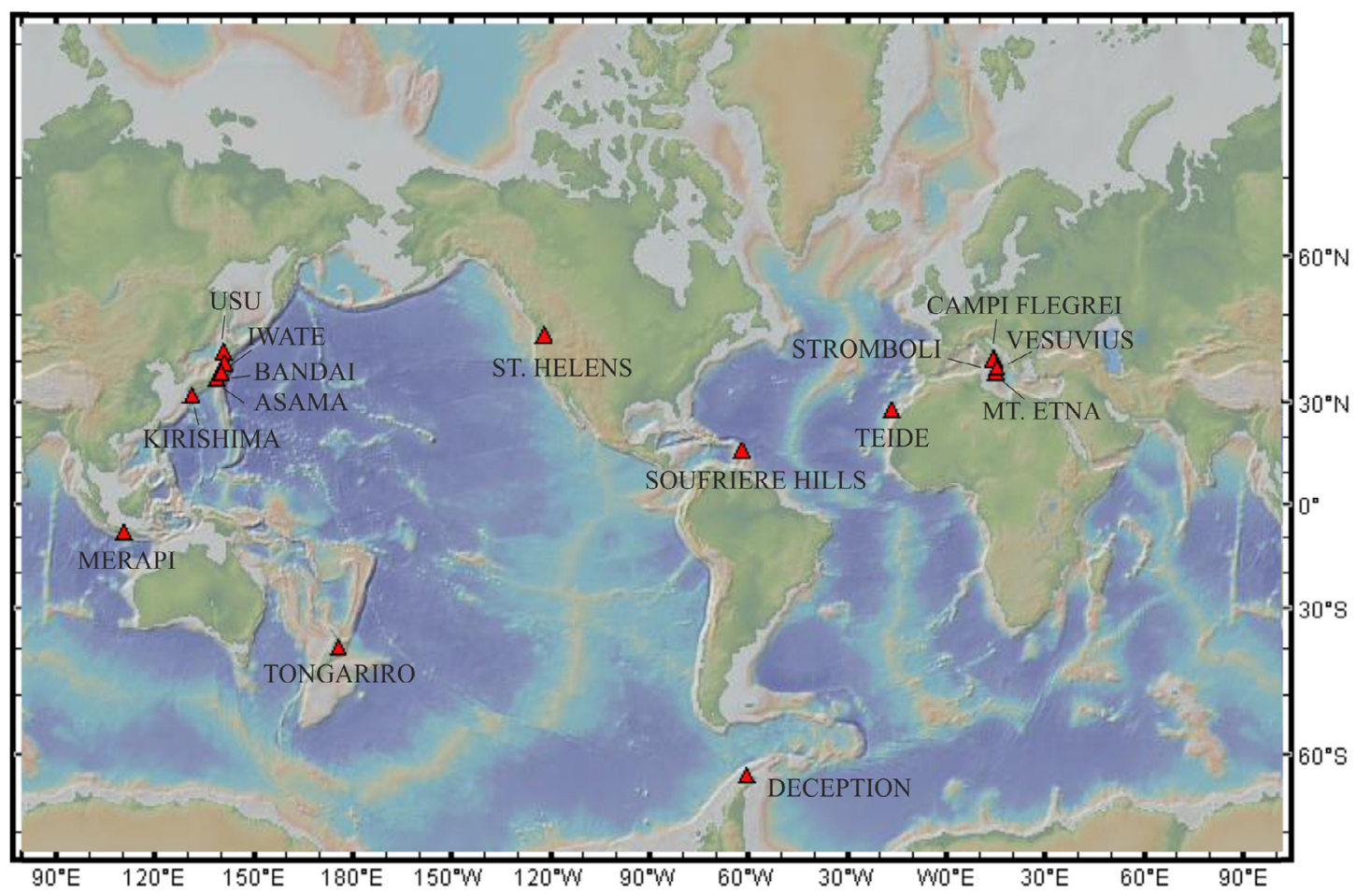

Figure 1. Map of the position of the volcanoes mentioned in the text and where active seismic experiments have been performed.

ranges from $4.5 \mathrm{~Hz}$ to $>150 \mathrm{~Hz}$ with a damping of 0.56. Additionally, some Mark L-4C-3D sensors were deployed with the Cube recorders (Figure 2c). These geophones are three-component and have a response from $1 \mathrm{~Hz}$ to $>100 \mathrm{~Hz}$ with a damping of 0.7 .

Further information about the data logger and the geophones can be found in GFZ Potsdam web-page (http: / www.gfz-potsdam.de/en/section/geophysical-

\begin{tabular}{ccccc}
\hline Device & Gain & LSB & $\begin{array}{c}\text { Sensitivity } \\
(\text { counts/volt })\end{array}$ & $\begin{array}{c}\text { Clip } \\
(\mathbf{p p})\end{array}$ \\
\hline CUBE3 & 1 & $244 \mathrm{nV}$ & $4.0984 \cdot 10^{6}$ & $4.1 \mathrm{~V}$ \\
& 16 & $15.3 \mathrm{nV}$ & $6.5574 \cdot 10^{7}$ & $0.26 \mathrm{~V}$ \\
EDL & 1 & $1 \mu \mathrm{V}$ & $1 \cdot 10^{6}$ & $16 \mathrm{~V}$ \\
\hline
\end{tabular}

Table 2. Main characteristic of the different acquisition systems used. deep-sounding/servicesinfrastructure/geophysical-in strument-pool-potsdam-gipp/instruments / seismic$\mathrm{pool} /$ ).

For TOMO-ETNA experiment we deployed 80 Cube stations with 78 3-D PE-6/B geophones and 2 Mark L-4C-3D geophones, some of them were transferred from one location to another during the experiment in order to maximize the network coverage.

\begin{tabular}{cccc}
\hline Device & Frequency & $\begin{array}{c}\text { Generator constant } \\
(\mathbf{V} \cdot \mathbf{s} / \mathbf{m})\end{array}$ & Damping \\
\hline PE-6/B & $4.5 \mathrm{~Hz}$ & 28.8 & 0.56 \\
MARK L-4C & $1 \mathrm{~Hz}$ & 180 & 0.7 \\
Trillium Compact & $120 \mathrm{~s}$ & 750 & 0.7 \\
\hline
\end{tabular}

Table 3. Main characteristic of the seismic sensors used.

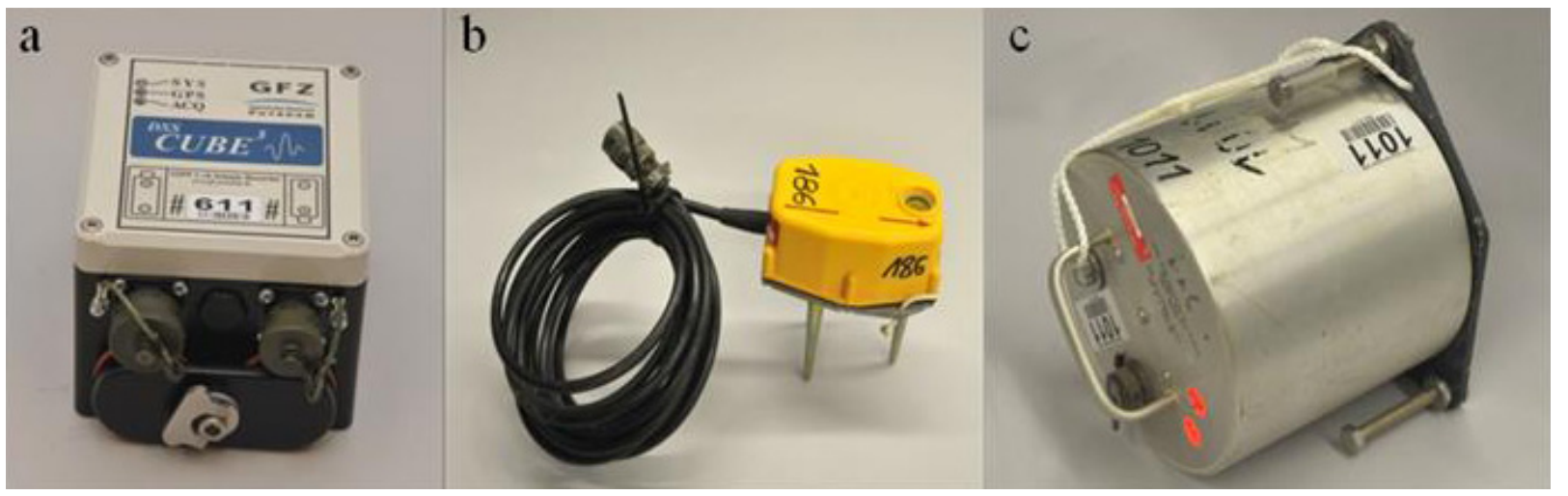

Figure 2. Short-period seismic stations deployed on-land during the experiment and belonging to the GIPP (Germany). (a) DATA-CUBE3 recorder; (b) 3-D PE-6/B Geophone; (c) Mark L4C sensors. 


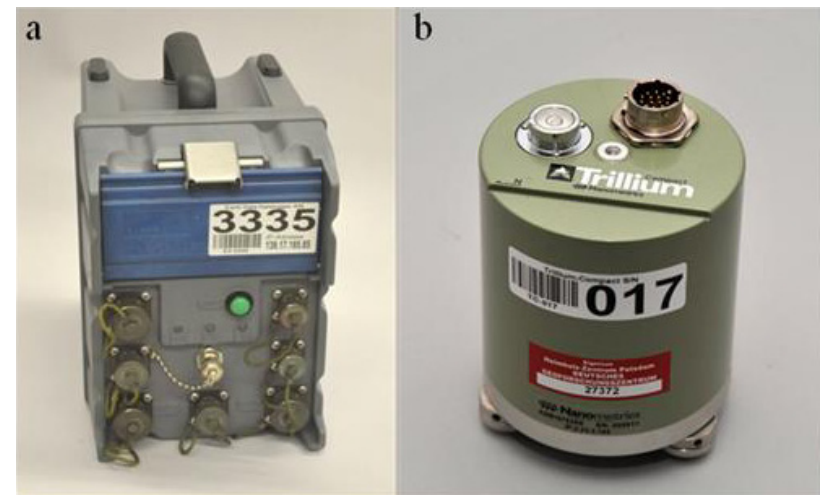

Figure 3. Broadband portable seismic stations deployed during the experiment. (a) EarthData PR6-24 three-channel recorder, and (b) Trillium Compact broadband three-component sensor.

\subsection{On-land broadband portable seismic stations}

On-land broadband (BB) portable seismic stations were provided by the GIPP, Germany [Ibáñez et al. 2016, in this volume]. They are composed of an EarthData PR6-24 recorder and Nanometrics Trillium Compact seismometer (Figure 3). The PR6-24 is a data logger for stand-alone use with three-channel digitizer with a $140 \mathrm{~dB}$ dynamic range at 100 sps of sampling rate. The seismometer is a Trillium Compact, a broadband three-component sensor with a flat response that ranges from $120 \mathrm{sec}$ to $100 \mathrm{~Hz}$. Its three symmetric triaxial sensors are resonance-free up $200 \mathrm{~Hz}$. These stations were powered with solar panels connected to a $75 \mathrm{Ah} 12 \mathrm{~V}$ batteries.

Further information about the broadband stations can be found in GIPP, GFZ Potsdam web-page (http:/ / www.gfz-potsdam.de/en/section/geophysical-deep- sounding/servicesinfrastructure/geophysical-instrumentpool-potsdam-gipp/instruments/seismic-pool/).

For TOMO-ETNA experiment we deployed 17 broadband stations that operated from June 20 to October 28, 2014. They registered not only the air-gun shots from the active experiment but natural seismicity occurred during the 4-month period, allowing us to increase and enhance the passive database [Barberi et al. 2016, in this volume].

In Figure 4 we plot the response curve for the Trillium Compact (+EarthData), the Mark L-4C (+Cube) and the PE6/B (+Cube) seismometers.

\subsection{OBSs}

\subsubsection{Spanish OBSs}

The Unidad Tecnológica Marina (CSIC-UTM, Barcelona, Spain) provided 15 ocean bottom seismic stations (OBSs). Their technical name is LC SP $4 \times 4$ IGPP-SIO-UCSD OBS, and they include a HighTech HTI-90-U hydrophone. The geophone is a short-period Sercel L28 model, with natural frequency of $4.5 \mathrm{~Hz}$ and a sample rate of 200 sps. Data logger and electronics are BART ORE Offshore software sampling at $200 \mathrm{sps}$ (Figure 5). The OBSs clock is Seascan TCXO (0.02-0.05 ppm), which must be synchronized with high-precision on-board GPS before deployment and recovery phases, in order to correct time shifts during the recording period. Usual time drift of this clock for 20 days is around $10 \mathrm{msec}$. These stations were powered with $12 \mathrm{~V}$ batteries with autonomy of 2 months.

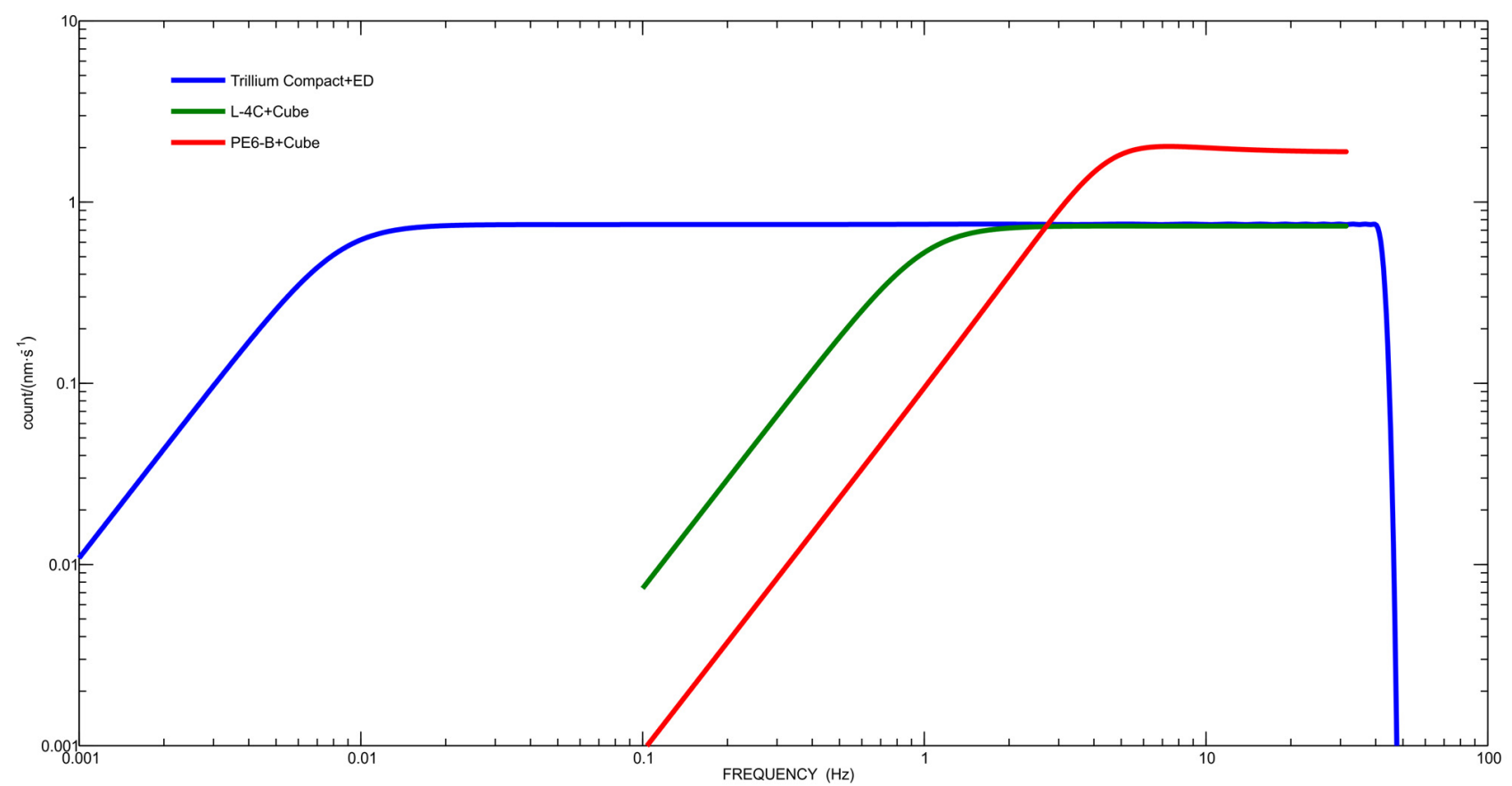

Figure 4. Response curve for the Trillium Compact (+EarthData), the Mark L-4C (+Cube) and the PE6/B (+Cube) seismometers. Curves have been calculated using the information described in the text. 


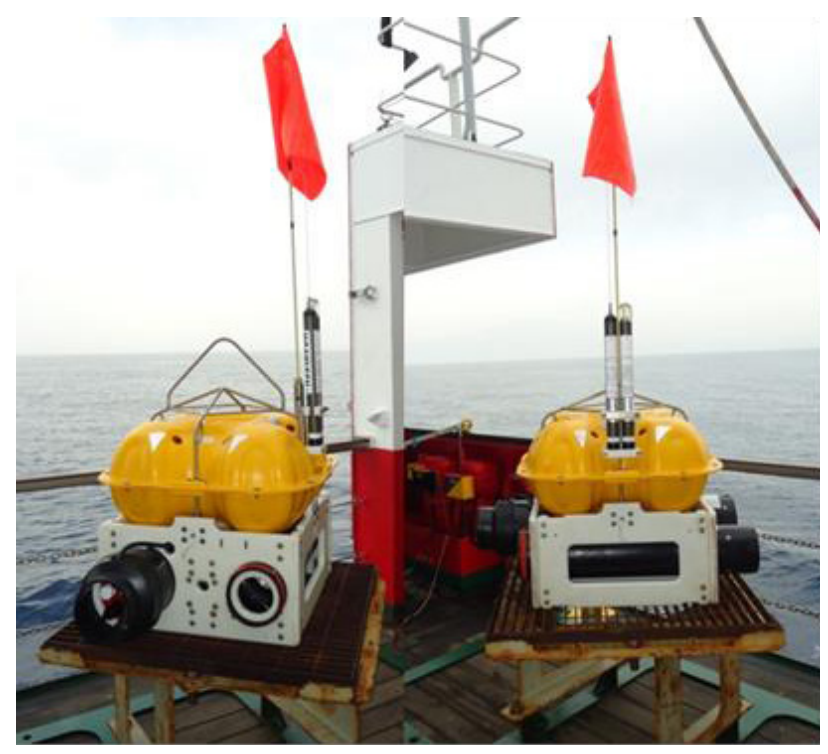

Figure 5. Spanish OBS.

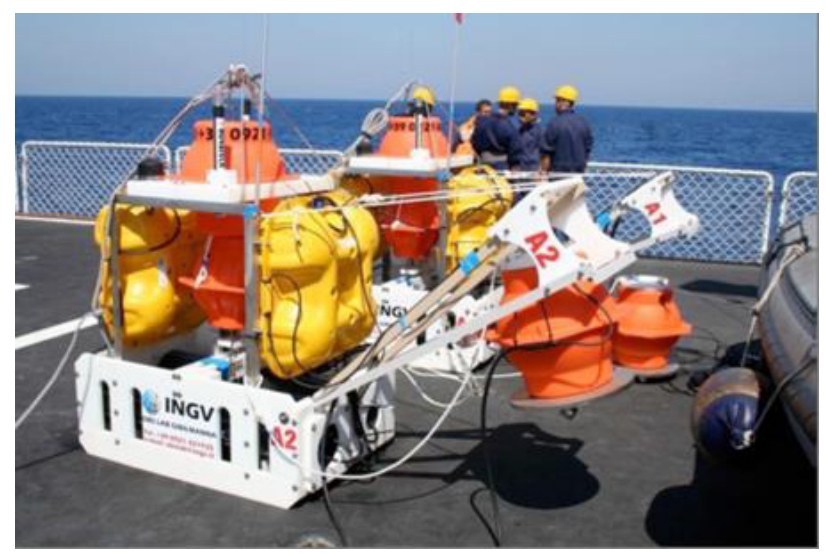

Figure 6. Italian OBS.

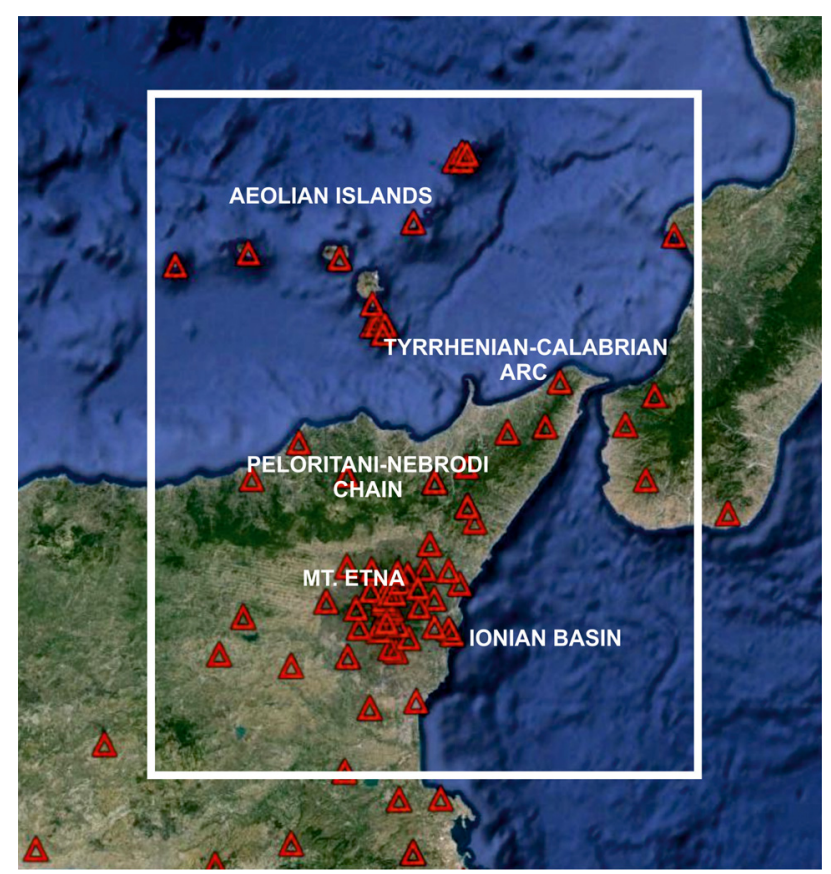

Figure 7. Map of the location of the seismic stations of the INGV permanent network, Italy, used in the TOMO-ETNA experiment.

\subsubsection{Italian OBSs}

The Observatory of Gibilmanna, near Palermo, run by Italy's Istituto Nazionale di Geofisica e Vulcanologia (INGV), provided two types of OBS stations to be deployed: i) short-period SM / 6 geophone registering within a frequency range of $4.5-140 \mathrm{~Hz}$ and with 250 sps; and ii) broadband Güralp CMG40T-OBS sensors that registered between $60 \mathrm{~s}$ and $100 \mathrm{~Hz}$ with a sample rate of 100 sps. In Figure 6 we show a picture of one of this OBS station. A total of 10 short-period OBSs and 2 broadband OBSs were used in this experiment. All seismic stations were powered with $12 \mathrm{~V}$ batteries with autonomy of 1 month for the short-period and 6 months for the BB.

\subsection{Array Pozzo Pitarrone}

Two broadband seismic stations of the permanent monitoring network are installed at Pozzo Pitarrone [Zuccarello et al. 2016, in this volume], one at surface (EPIT) and one at the well bottom (EPIP), at depth of about 130 meters. A temporary seismic array was deployed in the area around Pozzo Pitarrone between May and October 2014. The array consisted of 8 three component broadband stations arranged in two roughly concentric rings of radii $100 \mathrm{~m}$ and $200 \mathrm{~m}$ centered at EPIT station. The seismometers used for the array were Guralp CMG-40T 60 s (http: / / www.guralp.com) and Nanometrics Trillium 120 s compact (http: / / www. nanometrics.ca), and signals were acquired by Nanometrics Taurus data loggers recording at 200 sps, with 24 bits dynamic range.

\subsection{Permanent network}

We have used also the data recorded by the INGV permanent network operated by the Osservatorio Etneo (the INGV Etna Observatory; Figure 7). Seismic stations of this network are broadband three-component Nanometrics Trillium seismometers. These sensors have a period of $40 \mathrm{~s}$, a flat frequency response from $0.025 \mathrm{~Hz}$ and a sensitivity of $1553 \mathrm{~V} / \mathrm{M} / \mathrm{S}$. They register with a sample frequency of $100 \mathrm{~Hz}$ by a Nanometrics Trident digital system (24 bits). For TOMOETNA experiment we used the data registered in 71 seismic stations. The dataset is provided in DMX format, which is a simplified type of SUDS format. In this case, careful data processing was needed to transform DMX to a SAC format.

\section{Seismic sources}

\subsection{Air-gun signals}

Active seismic sources were provided by the Spanish oceanographic research vessel (hereafter, R/V) 
"Sarmiento de Gamboa" and consisted of 16 air-guns deployed along a two-line array $10 \mathrm{~m}$ below sea level (Figure 8 ). The volume of the guns was of: $520 \times 4$, $380 \times 4,250 \times 4,150 \times 4$ cu.in.; having a total volume of $5200 \mathrm{cu}$.in. They were spaced $1 \mathrm{~m}$ from each other, within the line, and $9 \mathrm{~m}$ between different lines. For the TOMO-ETNA refraction experiment the air-guns shot every $90 \mathrm{~s}$, while for the reflection experiment was of 20 s with a $4340 \mathrm{cu}$.in. of total volume.

The signal associated to this bubble is simulated using a software package named GUNDALF (Figure 9). Before the onset of the experiment, many tests were performed by the Unidad de Tecnología Marina (UTMCSIC, Spain) to obtain the most efficient distribution and power of the guns. The tests carried out permitted to adjust several parameters for an optimal configuration of the guns that lead to the most efficient output signature. The chosen signature has a dominant frequency of $20 \mathrm{~Hz}$ and a total acoustic energy of $479,939.9 \mathrm{~J}$ and an acoustic efficiency of $40.8 \%$ (Figure 9). In Figure 10 we show a picture of the real bubble generated by the air-guns mounted in the Spanish R/V "Sarmiento de Gamboa”.

\subsection{Earthquakes}

A total of 452 earthquakes were selected from the INGV database for the period June 1st to November 30, 2014. The preliminary filter was done on the base that they must be recorded in at least three seismic stations from the permanent INGV network, and inside the re-
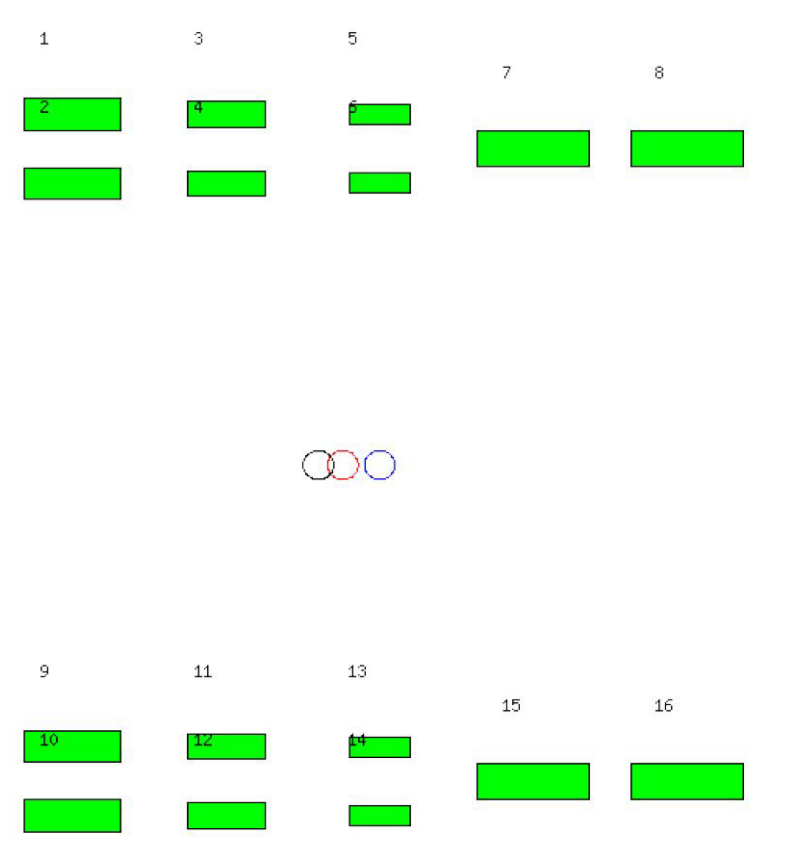

Figure 8. Spatial configuration of the array of air-guns mounted in the vessel "Sarmiento de Gamboa" used in the generation of the active seismic signal during the WAS campaign. Circles represent the theoretical position of the highest energy bubble obtained with this array of air-guns. gion selected for this study. In Figure 11 we plot the epicenters of the selected seismicity. The magnitude $(\mathrm{Mw})$ of these events ranged from 0.3 to 3.8 , and the focal depths were from $1.5 \mathrm{~km}$ above sea level (Etna edifice) to $215 \mathrm{~km}$ below sea level (subduction structure below Aeolian Islands). The selected period of time was chosen in order to produce a seismic tomography as a snapshot of the structure of the region. As Barberi et al. [2016, in this volume] evidenced, the continuous magmatic dynamic of the volcanic structure produce significant changes in the physical properties of the volcanic region, and therefore changes in the velocity patterns. If a larger time interval for the earthquakes was selected, we could introduce a bias in the final picture of the structure due to potential changes of the velocity values, mainly in the Mt. Etna edifice and roots. In Barberi et al. [2016, in this volume] there is an exhaustive description of the seismic and volcanic activities of the region and in Mt. Etna during the period of the experiment.

\section{Land operation}

\subsection{Search of the sites}

The on-land phase started with the search of the potential places to locate the portable seismic stations. This is a very important and sensitive step since a careful selection of the site will permit to deploy efficiently and safely the seismometers. This search was done imposing a series of quality criteria to place a seismic sensor:

(a) low ambient/cultural/volcanic noise level

(b) protected and safety sites

(c) easy to arrive and maintain

(d) consolidated host rock.

Initially, an area of $5500 \mathrm{~km}^{2}$ was selected as the region to deploy the stations. The size was estimated taking into account the main objectives of the project: to produce a seismic tomography of Mt. Etna volcano and surrounding areas in order to place this volcano in a regional framework. This zone comprises the eastern coast of Sicily and Mt. Etna volcanic edifice (see Figure 1 of Ibáñez et al. 2016, in this volume]. Although the area under interest comprises part of eastern Sicily Island, the Aeolian Islands and part of the south of the Italian Peninsula (Calabria), since in both Aeolian Islands and Calabria the permanent INGV seismic network has several stations, we centered our efforts exclusively in Sicily Island. The first step was to place on a map a set of 200 theoretical locations for the portable seismic stations according to the above quality requirements. Once this preliminary map was defined, from the beginning of April to the end of May of 2014 a team led by A. Díaz-Moreno from the UGR and O. Cocina from 

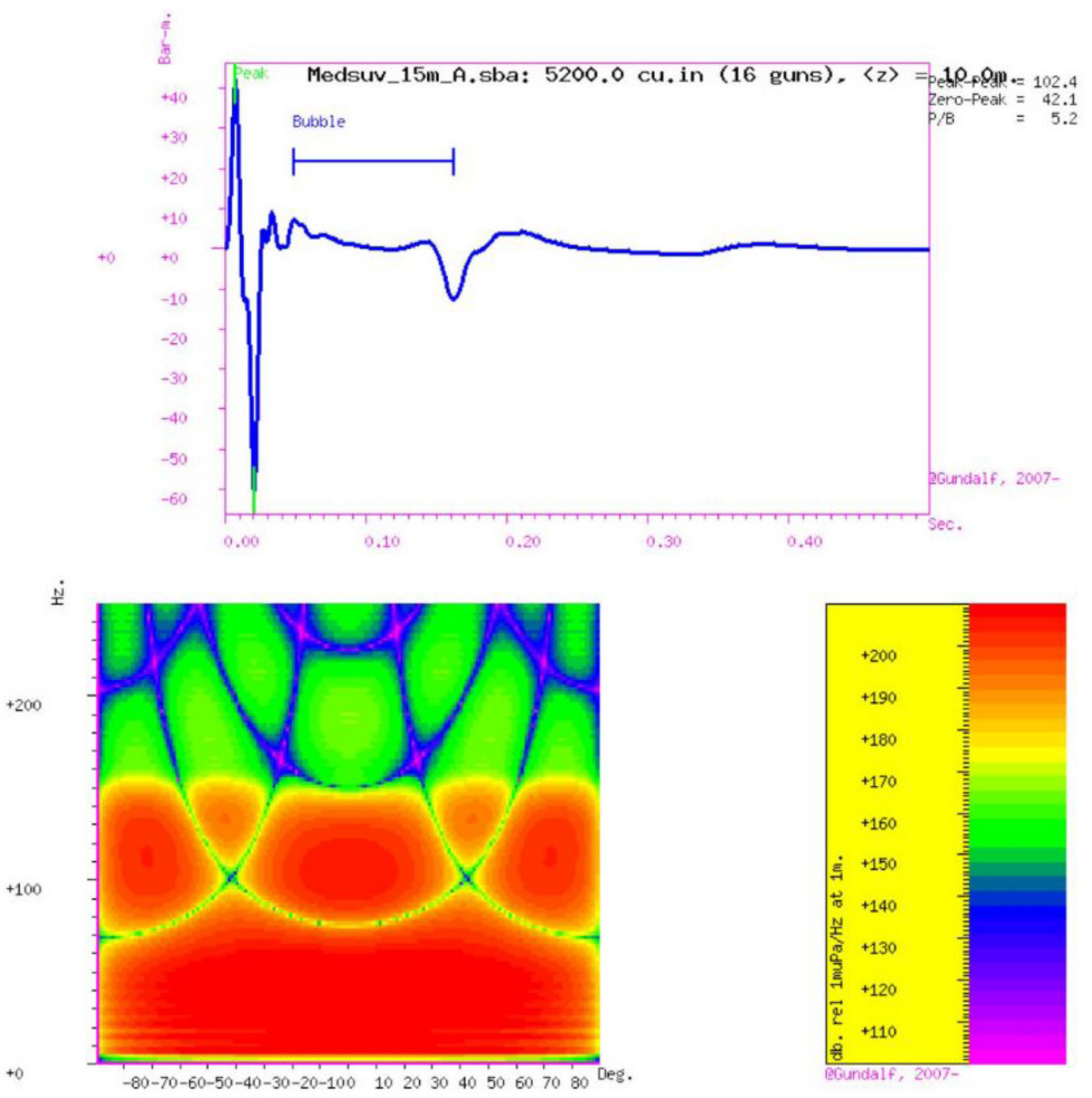

Figure 9. Theoretical pulse of the active air-gun source performed during the WAS campaign in the time and the spatial domain.

the INGV, Section of Catania (hereinafter: INGV-Catania), with the support of several researchers of the

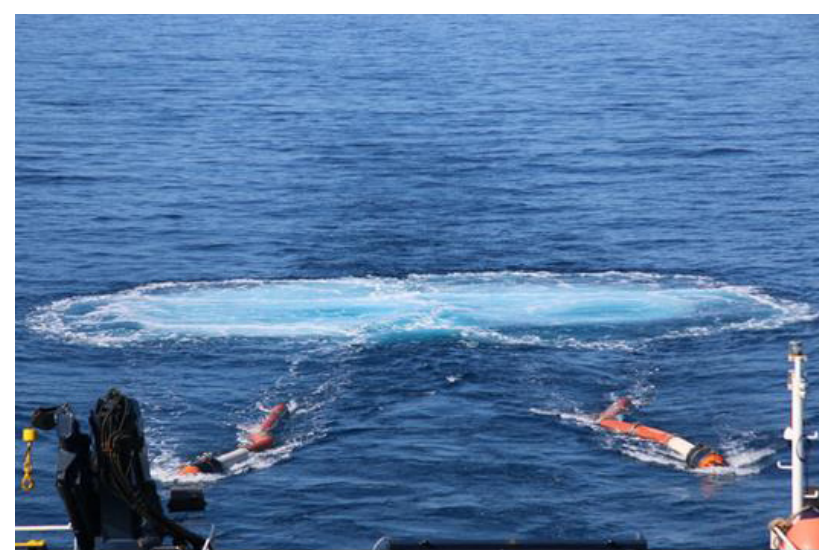

Figure 10. A picture of the real bubble generated by the air-guns mounted in the vessel "Sarmiento de Gamboa".
INGV-Catania, visited each of these locations, in some cases more than once. Finally 150 potential locations were selected covering almost homogeneously the region of interest. The work of this team included to stablish contact with the private owners or the public authorities responsible of the sites and asking for permission for the temporal deployment of the seismic stations. Official documents were provided by the INGV in order to have an additional support in this negotiation. Preferentially they selected public properties such as cemeteries, parks or schools (the planned shooting period was during a non-teaching season). If no public properties were identified, then private areas with the possibility of restricted access were selected such as farms, rural hotels, and golf resorts. In the Mt. Etna region, the special protected area due to the Natural Park declaration facilitates this search and location of sites. 


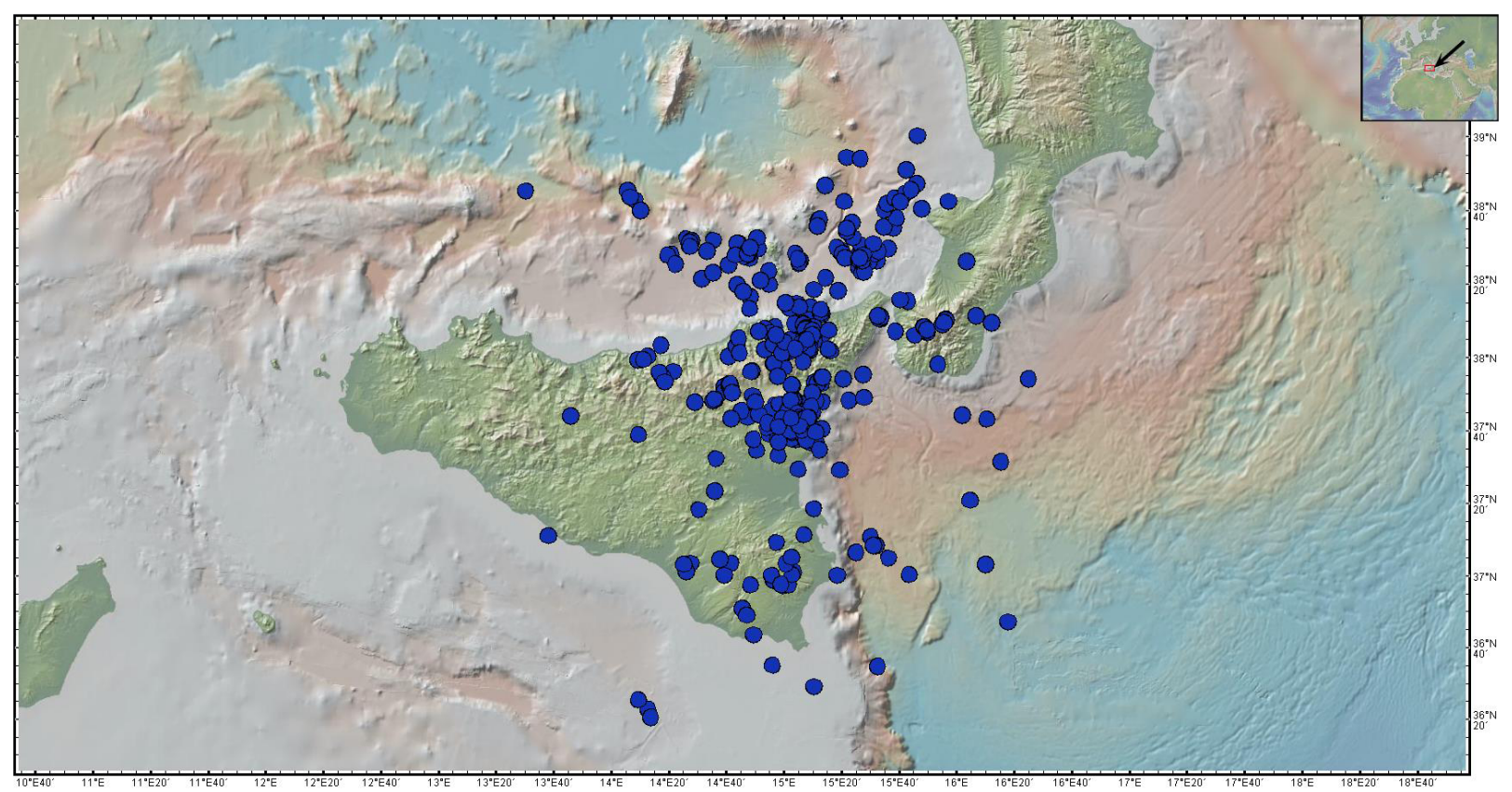

Figure 11. Maps of the 452 earthquakes occurred between June and October 2014, used in the TOMO-ETNA experiment.

The Natural Park facilities were also used for several stations placed in the Peloritani Mountains.

In several times, the researchers had to convince both authorities and private owners of the importance of the experiment. Many private owners were concerned about possible health issues regarding the installation of the stations (the most repeated question done for many owners was if the seismic stations had any level of radioactivity or how noisy they could be, or the possible consequences on their properties deriving from the 'measurements' of earthquakes). The search teams were always composed by at least one Italian researcher from the INGV due to of the importance of having a local and institutional representative.

The BB stations needed additional requirements such as a place to install solar panels and consolidate and cover basement since they will be operating for longer time. Furthermore, their objective was to record natural seismicity generated by Mt. Etna volcano, and therefore they must be located close to the volcano edifice. Therefore most of the selected places for the portable BB stations were placed already used for the allocation of other geophysical or geochemical instruments.

At the end, mostly of the selected places were public sites. As a curiosity we can mention that more than 25 cemeteries were used to install seismic stations. Indeed, no robbery or damage of any instruments had been reported during the experiment. At the end of the experiment the only risk that the seismic stations were exposed to were forest-fires and the disturbance from farm animals. In any case we were lucky and no damage was reported. As an example, near the village of Catenanuova a fire was declared. Flames stopped just few meters from the station as illustrated in Figure 12.

In total around $10,000 \mathrm{~km}$ were driven by the different teams during the search period. Once a site was identified as suitable, the search team prepared a document containing information on the location, details

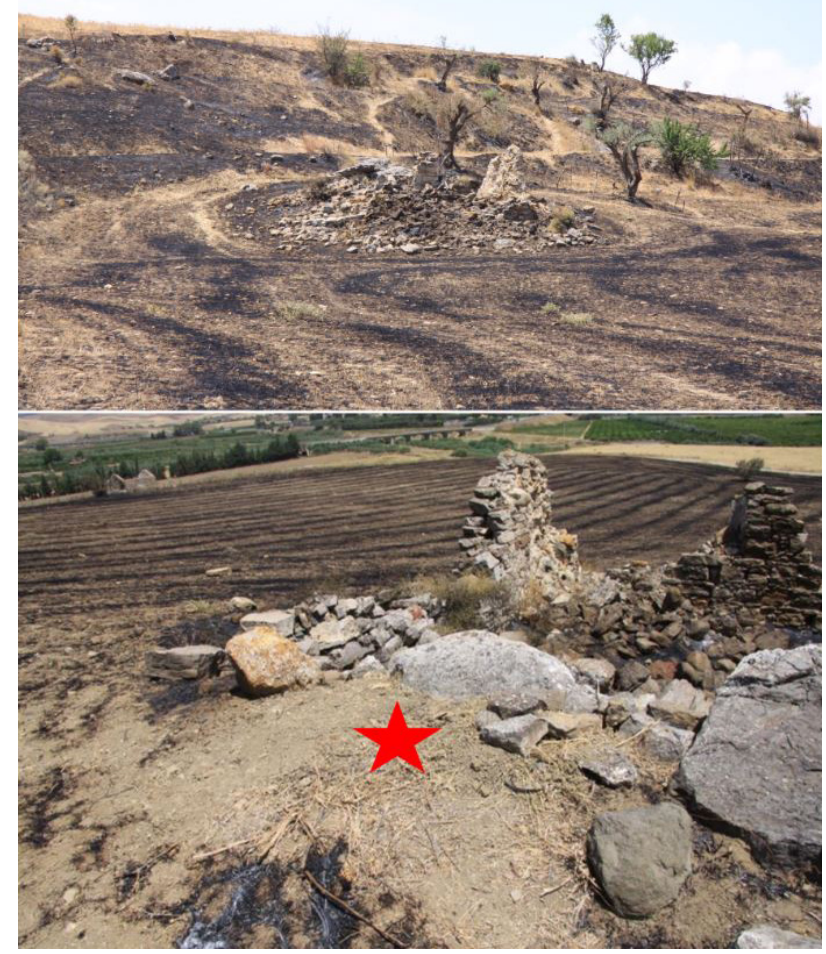

Figure 12. Pictures showing the rests of a fire near the location of a seismic station. Red star marks the station position. The fire covered a big area all around the station but no damage to the instruments has occurred. 
E045 CAT- North E-46 Regalbuto (CT)

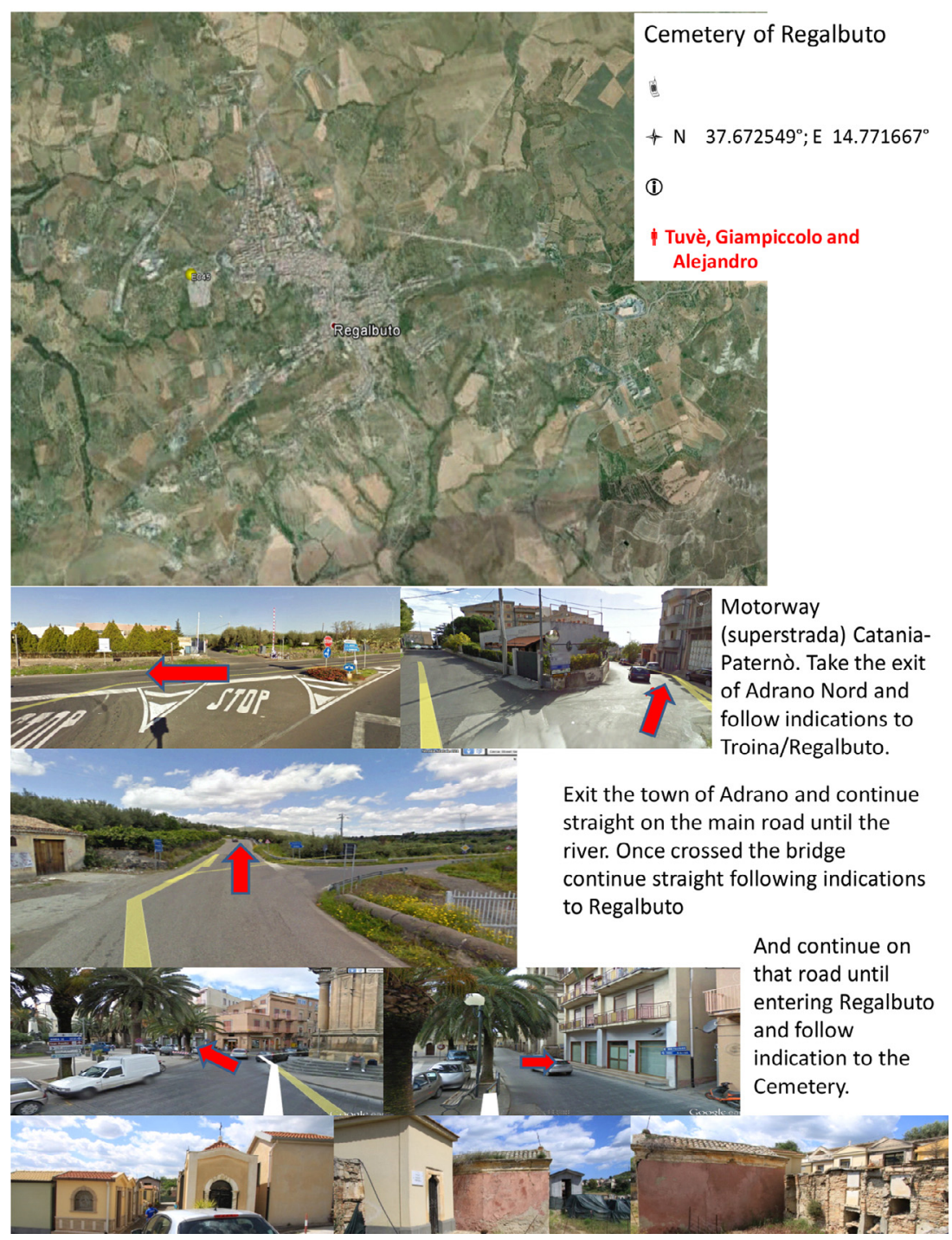

Figure 13. Information slides of one site selected for station location. In this case it is the Cemetery of Regalbuto town. From all potential locations described in the book, we selected the best 100 places following the criteria described in Section 4.1 and geometrical constraints to obtain a dense regular grid for the seismic network.

the rest of the scientific community working at Mt. Etna volcano.

Due to the large extension of the region under study, once the best sites were identified the whole region was divided in four sectors with an almost same number of seismic stations contained in each one. In each sector a city or village was selected and placed to accommodate the researchers responsible of the deployment, maintenance and recovery of the seismic stations. The four subteams were located in the city of Catania and in the towns of Randazzo, Milo and Villafranca.

\subsection{Deployment}

In June 16, 2014, the TOMOETNA active seismic experiment, officially started with a preparation of the seismometers to be deployed at the Etna volcano and surrounding area. The first activity carried out in this new phase of the experiment was the revision of the seismic stations provided by the GIPP-GFZ institute, 80 short-period and 20 broadband stations. All equipment were stored in the INGV headquarters in Nicolosi and it was necessary to transport a large amount of material from Catania to this place. In Figure 14 we illustrate this process of transportation and storage of the equipment.

On June 17 a training session

about driving instructions, owners' contacts, photos, etc. In Figure 13 we report an example of this type of document. All these documents were compiled in an electronic and printed format under the coordination of A. Díaz-Moreno and with the collaboration of Italian and Spanish researchers. The aim of this book was to allow to the deployment teams to arrive promptly to the locations. Taking into account that many of the researchers involved had never visited the place, the information should be very accurate and detailed. It is noteworthy that this information was a complete success since all the researchers were able to reach the locations without major problems, leading to a much more efficient work. At the present it is planned to print the complete information (more than 250 pages of data) in a type of open file report in order to be accessible to for the use of the equipment was programmed for a selected group of Italian and Spanish researchers (deployment team leaders) that will be responsible for a process of further training to the other researchers. This first training was performed by Prof. B.-G. Lühr from the GFZ of Potsdam (Germany). In Figure 15 we illustrate this process. On June 18 and 19 this team of leaders deployed some of the seismic stations in some sites near the Etna volcano under the supervision of Prof. Lühr in order to check the right operation procedure and to test potential mistakes, faults or other minor problems. On July 20 the whole TOMO-ETNA team (a great part of the non-Italian researchers arrived on June 19) participates in a new training session in $\mathrm{Ni}$ colosi and received the seismic stations that each subteam must deploy. As a part of the training process each 

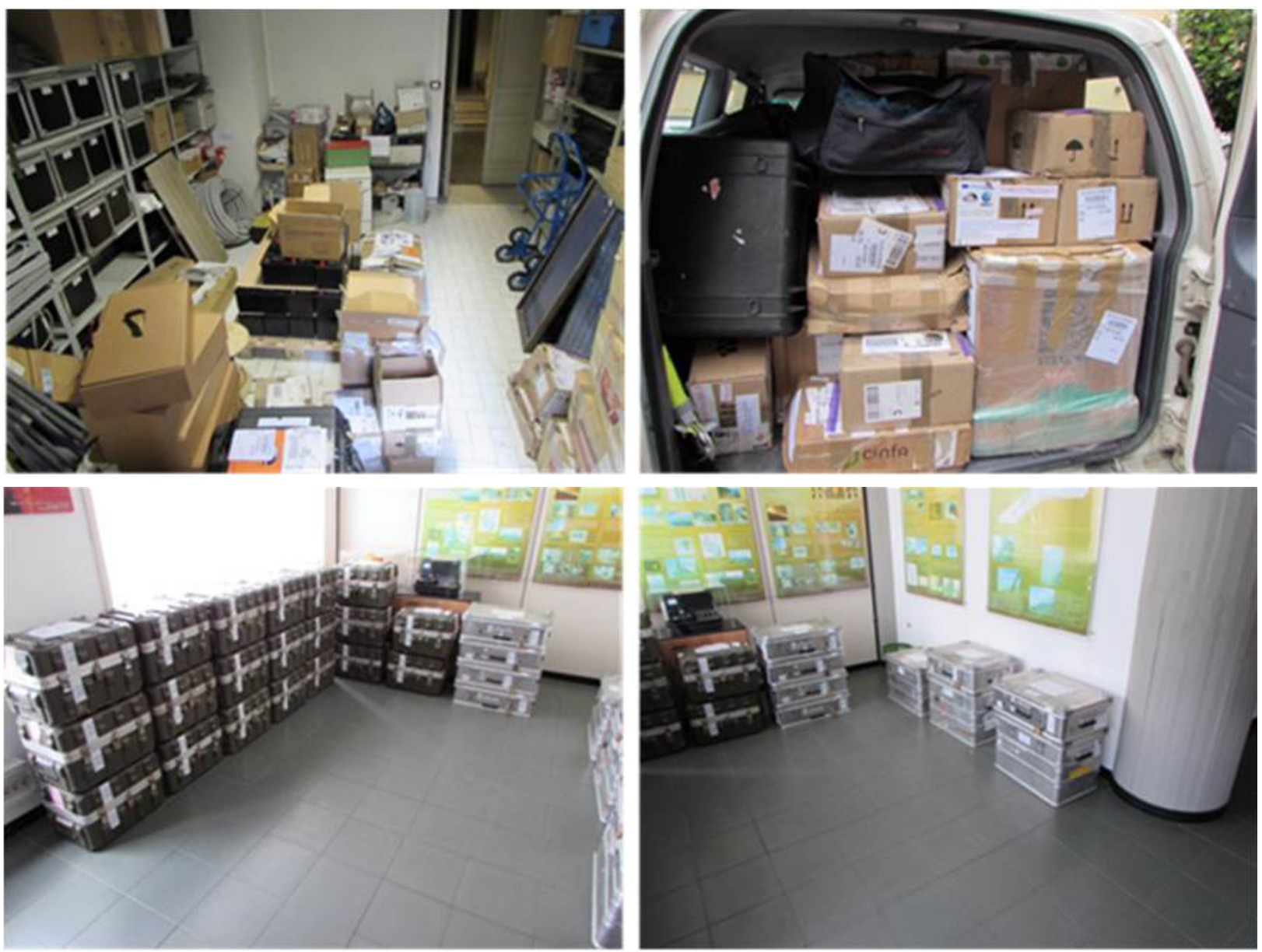

Figure 14. Transport and storage of the sensors of the portable seismic network before their deployment.

team received the information of the pre-selected sites to deploy the seismic stations. This information was presented in the document described in Section 4.1.

For each seismic station we require the compilation of a file with technical information associated to the instruments and deployment procedure. In Figure 16 we show an example of this sheet.

Each of the four working groups was equipped with: - a station wagon and a van

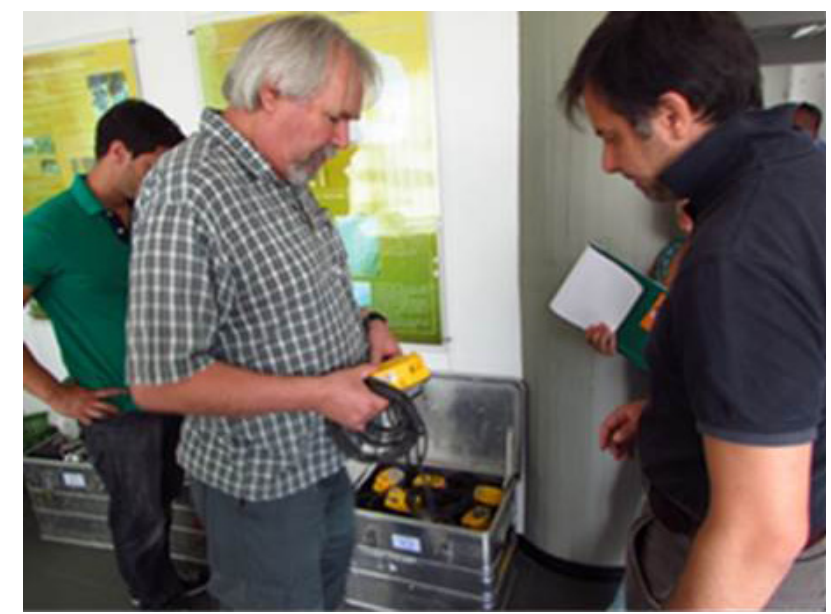

- a smartphone with Italian card, including internet connection and a GPS application

- four halogen headlamps with batteries

- a toolbox with various kinds of screwdrivers, pliers, wrench, scissors, electrical duct tape, duct tape, gloves, compass, level and a tester

- two picks, two shovel and two hoes

- a fluorescent jacket for each person with identification of the project, INGV and UGR

Figure 15. The first training lessons on the use of the seismic stations provided by Prof. B.-G. Lühr from the GFZ of Potsdam (Germany). 
- two back-packs of 50 liters of capacity to transport sensors and batteries

- their correspondent number of data logger, seismometers and batteries, including batteries of replacement for the data logger

- a folder with the information of their respective stations (instruction of use, replacement and maintenance), sites and routes to arrive to them

- a clear identification sheet stating that the car and the persons in it belong to the INGV-Catania and to the MED-SUV project and TOMO-ETNA experiment.

Additionally we were supported by different INGV technicians from Catania, Rome, Naples and Bologna. These technicians were in charge of the deployment of the BB stations.

In June 23 the deployment started. The workingplan for the deployment was conceived in order to optimize the different assigned routes and to deploy the seismic stations as fast and safe as possible. In Figure 17 we plot the initial planned sites distributed according the different working teams and we mark, as an example, the routes followed by the different teams in one day of work. Additionally, in Figure 18 we illustrate the installation process. As a summary of the number of seismic stations deployed:

(a) Villafranca group: 14 short-period seismic stations

(b) Randazzo group: 18 short-period seismic stations

(c) Milo (Etna) group: 12 short-period seismic stations

(d) GPS technicians: 8 broadband seismic stations

(e) seismiological technicians: 6 broadband seismic stations

(f) Catania group: 4 broadband and 36 short-period seismic stations.

In June 26 the $95 \%$ of the seismic stations had been deployed in their different sites according with the preestablish selection. The final map with the sites of the whole seismic network deployed for the TOMO-ETNA experiment, including the permanent seismic network of the INGV, is presented in Figure 18.

\subsection{Maintenance}

After the phase of installation of the seismic stations, each group developed activities of maintenance and control. These activities were focused mainly in controlling the proper operation of the seismic stations and in changing the batteries every 7 days to ensure data acquisition. To avoid potential vandalism on the seismic stations, every site was visited at least once every 2 or 3 days.

As routine procedure, every day the operation coordinator, Dr. J. Prudencio, contacted each headquarter to indicate the activities of the day, potential changes, recovery information and potential problems, including helping other teams reaching the sites.
TOMO-ETNA STANTION CODE: E

\begin{tabular}{|l|}
\hline Instrument Serial Number \\
\hline Sensor (geophone) Serial Number \\
\hline Hard Disk Serial Number (fox 8s) \\
\hline Installation person/people \\
\hline Place of installation (+ coordingtes) \\
\hline Date (day-hour) of installation \\
\hline Type of batteries (soar ponel, ootteries, etc) \\
\hline Charge \\
\hline Photos \\
\hline Commentaries/Problems/Suggestions \\
\\
\end{tabular}

Figure 16. An example of the technical sheet that had to be compiled for each seismic station.

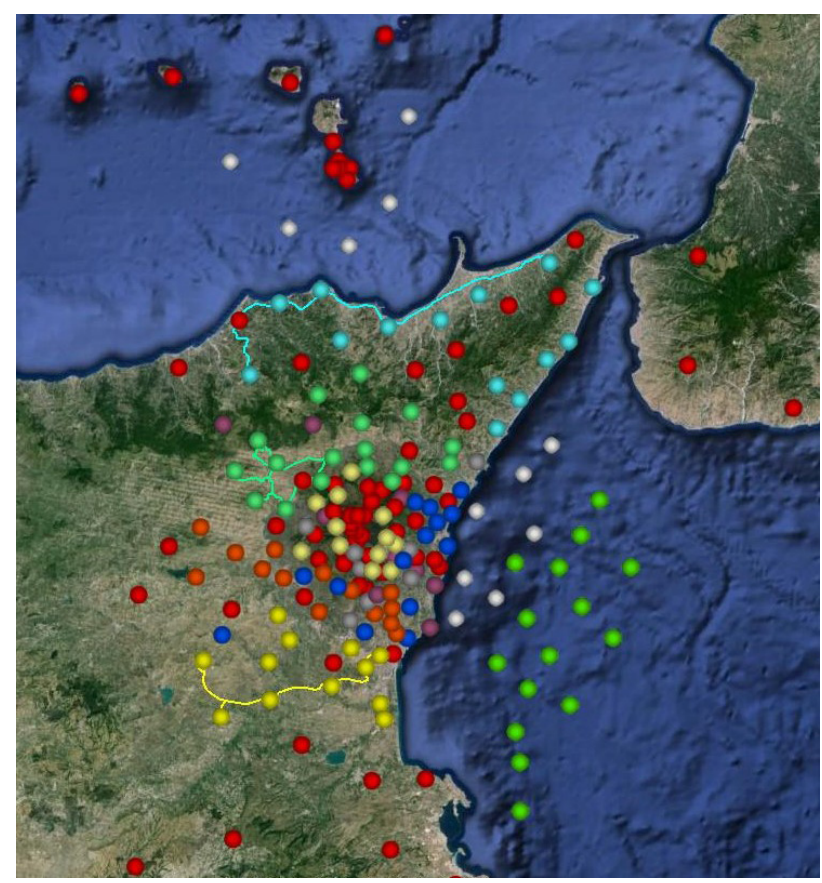

Figure 17. Final map of the deployed stations, different colours represent the deployment teams that were in charge of them. Red dots are the stations from the permanent network of the INGV. Yellow dots are stations for the South-Catania team; dark-blue dots for the East-Catania team, orange dots are West-Catania team; light yellow dots are Etna-team; grey and purple dots are INGV-technicians team; light green dots are Randazzo team; light blue are Villafranca team; green dots are the Spanish OBSs; and white dots are the Italian OBSs. Coloured-lines show some examples of daily team routes (>200 km each). 

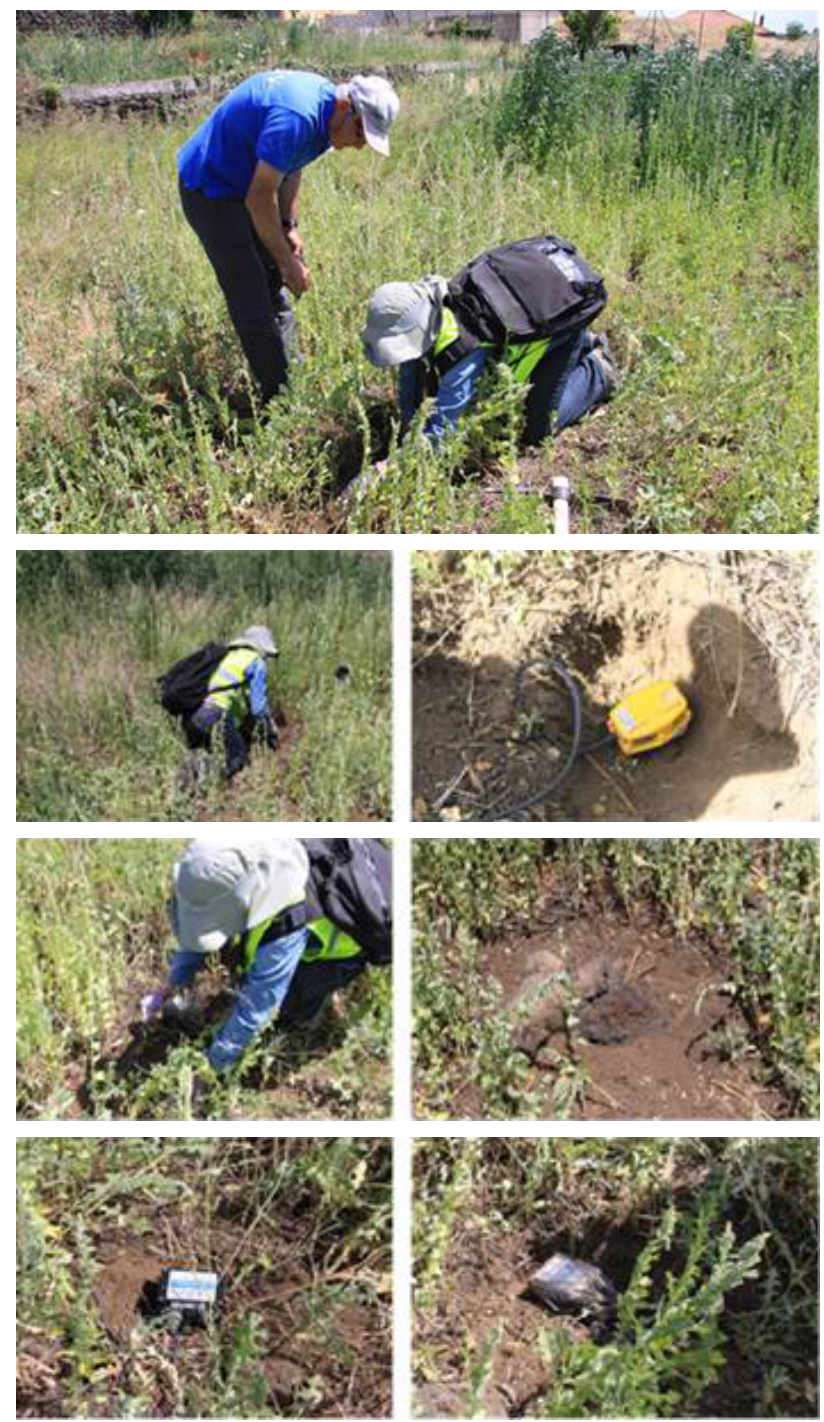

Figure 18. Different stages of the deployment of the seismic stations.

During the second leg of the shooting process, after July 10, some of the short-period seismic stations were moved from their original planned sites to new one in order to cover additional sites and improve the spatial distribution. In total 23 short period-stations were moved. In this case the initial planned 98 portable station sites were increased to 121 sites.

\subsection{Recovery}

On July 24, 2014, the active phase of the seismic experiment TOMO-ETNA ended. At this date the whole portable short-period seismic network was recovered. The broadband seismic network remained operative until October 28, 2014. At the same time the R/V "Sarmiento de Gamboa" arrived to the Catania harbor after the recovery of 21 short-period OBSs. The rest were recovered by the R/V "Aegaeo" in November 25,2014 . The uninstallation process of all seismic stations was a success and all the recovered instruments were fully operating and with no damages. In total, more than $25,000 \mathrm{~km}$ were driven during the experiment. In Figure 17 we show the final position of the whole stations used in the TOMO-ETNA experiment.

\section{Seismic signals}

\subsection{Seismic data bases}

The TOMO-ETNA dataset comprises 26,364 airgun shots (9705 refraction shots and 16,659 reflection shots) registered in 80 short-period, 17 broadband, 27 ocean bottom stations (OBSs) (15 provided by the Spanish team and 12 by the Italian team) and 70 broadbandshort-period (INGV permanent network) stations, summing 5,140,980 seismic signals. In Figure 19 we illustrate the route followed by the R/V "Sarmiento de Gamboa" during the whole shooting process. For additional information of the marine activities see Coltelli et al. [2016, in this volume]. For the refraction experiment we have a database of 1,892,475 seismic signals (including all stations). Additionally we recorded a total of 452 earthquakes in a dense seismic network. When the magnitude of the earthquake was larger than 3.0 it was recorded in more than 50 seismic stations. In Figure 20 we show an example of a regional earthquake recorded by this network. Red dots indicate the estimate P-wave onset determined by using an automatic algorithm described by Álvarez et al. [2013] and García et al. [2016, in this volume].

In general the quality of the signal is high. Due to the large area covered in this experiment, it was not possible to record the air-gun shots in the whole seismic network. In average the maximum distance shootstation to have good quality was of around $50 \mathrm{~km}$. In Figure 21 we plot an example of 3 hours of shooting period recorded by a single station. Red starts indicate, as in the case of the earthquakes, the estimated P-waves onsets of every explosion calculated automatically. In order to show the quality of the recorded signals we plot an example of a single shot recorded in four types of seismometers (short-period, broadband, permanent and OBSs) at different distances (Figure 22). It is remarkable how the signal has been filtered by the medium. As indicated in the characteristics of the active source, the theoretical source spectra are wide, between 4 and 40 $\mathrm{Hz}$. However the spectrograms of the recorded signals show a peak of amplitude, between 6 and $15 \mathrm{~Hz}$. This observation was used to select a filter between 4 and 12 $\mathrm{Hz}$ for the signal analysis in the tomographic inversion [Díaz-Moreno et al. 2016, in this volume].

\subsection{Database managing}

The first step was the unification of the data formats, because all the seismic data are recorded in a dif- 


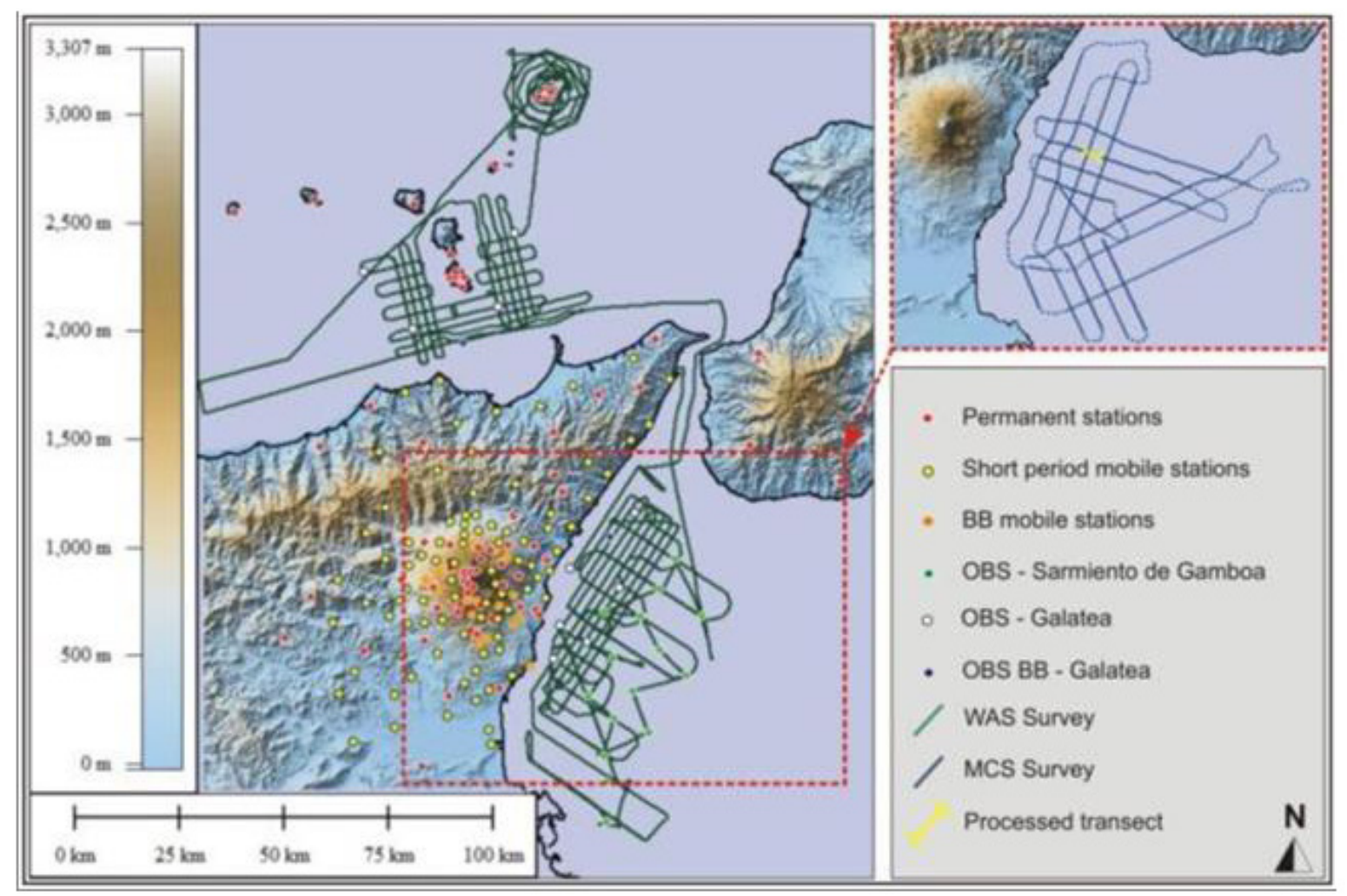

Figure 19. The whole route followed by the research vessel "Sarmiento de Gamboa" during the shooting period.

ferent formats depending on the station features (shortperiod, broadband, OBS, etc.). This procedure is not as easy as it may seem, since it is a very sensitive procedure. In the following paragraphs the different original formats and their conversion are detailed. Our preferred format to work with is .mat (matlab) so that we can process the data in a less time-consuming way.

We analyzed separately both earthquake and shots data. For the shot database we started with the Cube stations. These stations save the data in binary daily files that should be then converted to an appropriate format. The GFZ Potsdam institute provides useful algorithms to convert Cube format to MiniSeed format. During the recorded period, many of the 80 stations deployed lost the GPS signal sometimes, leading to more than one daily file. We found out that the registered data had some gaps, meaning that for certain periods of time the station did not register. The most probable cause of this is the loss of GPS signal. Fortunately, MiniSeed files are written with an absolute scale of time, thus, allowing us to identified and exclude these gaps. Another step we performed was to convert MiniSeed into SAC in order to choose the more suitable type file to work with. On the other hand SAC files have the time information not in absolute values but in a single time vector from 1 to the end of samples. Therefore, gaps could not be well identified using this type of files. For this reason we decided to work directly with the MiniSeed data. To reduce computation time we transformed the data into .mat format taking only the pieces of signal we needed. Indeed, we cut the signal $30 \mathrm{~s}$ before that data and $60 \mathrm{~s}$ after each shot. When we find a gap in the registration, the shots occurred in that period were not taken into account for that station.

Once the Cube database is organized in the new format, we plotted all shots registered at one station during one day using Matlab tools. This way of representation allows us view the movement of the vessel and to estimate the acoustic wave $(1.5 \mathrm{~km} / \mathrm{s})$ registered on the stations near the coast. Indeed, controlling the arrival time of the acoustic wave is a simple and very effective procedure to check that the GPS data times are correct, and that there is synchrony between the GPS data time of the air-guns and the stations.

The data extracted from the broadband stations are in MiniSeed format; therefore not further conversion is needed, only into .mat files. In this case we followed the same procedure as for the Cubes, we took the time data of each explosion to cut the MiniSeed file $30 \mathrm{~s}$ before it and $60 \mathrm{~s}$ after it and save it in Matlab files. The only problem we addressed in this step was that the coordinates of the broadband stations were daily calculated and differ from one day to another in some decimals. In order to have a final station coordinates we calculated the mean of all these daily GPS coordinates.

The INGV permanent stations provide data formatted in .DMX files, which result to be a compressed type of .SUDS files. This type of file is organized in a 


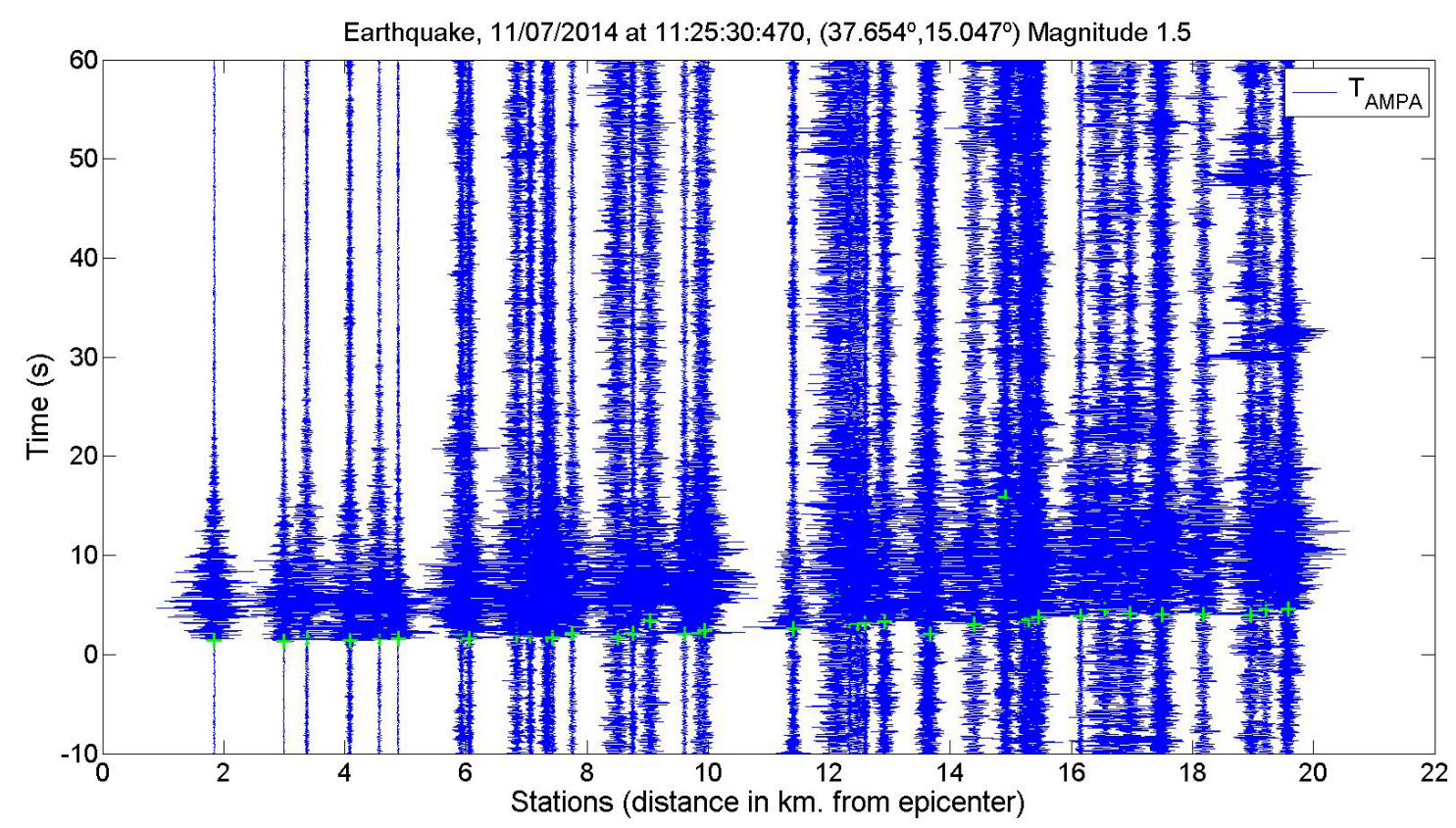

Figure 20. An example of a volcano tectonic earthquake recorded in several portable seismic stations of the TOMO-ETNA experiment located around Mt. Etna volcano. This earthquake occurred in July 11, 2014.

completely different way as the previously mentioned MiniSeed or SAC. They save registration of $1 \mathrm{~min}$ for each station. In this case, the INGV research team provided the necessary tools to convert them to a user-friendly SAC format. In any case we may address the same problems as with the Cube data; if any gaps are present we will not be able to detect them with the SAC format. Nonetheless, we converted them into .mat files following the previously discussed procedure and fortunately, we found no gaps in the registration of these stations.
The Spanish OBS data are provided in RAW binary format. The tools for conversion permit to obtain an output format known as PascalSegy. This data files were, then, organized in the common .mat files for their analysis.

The Italian OBS data available at the time of this report are only those recorded by the broadband OBSs. These data are saved in SAC files and therefore easy to handle. The procedure was the same as for the rest of data, obtaining .mat files as the final format.

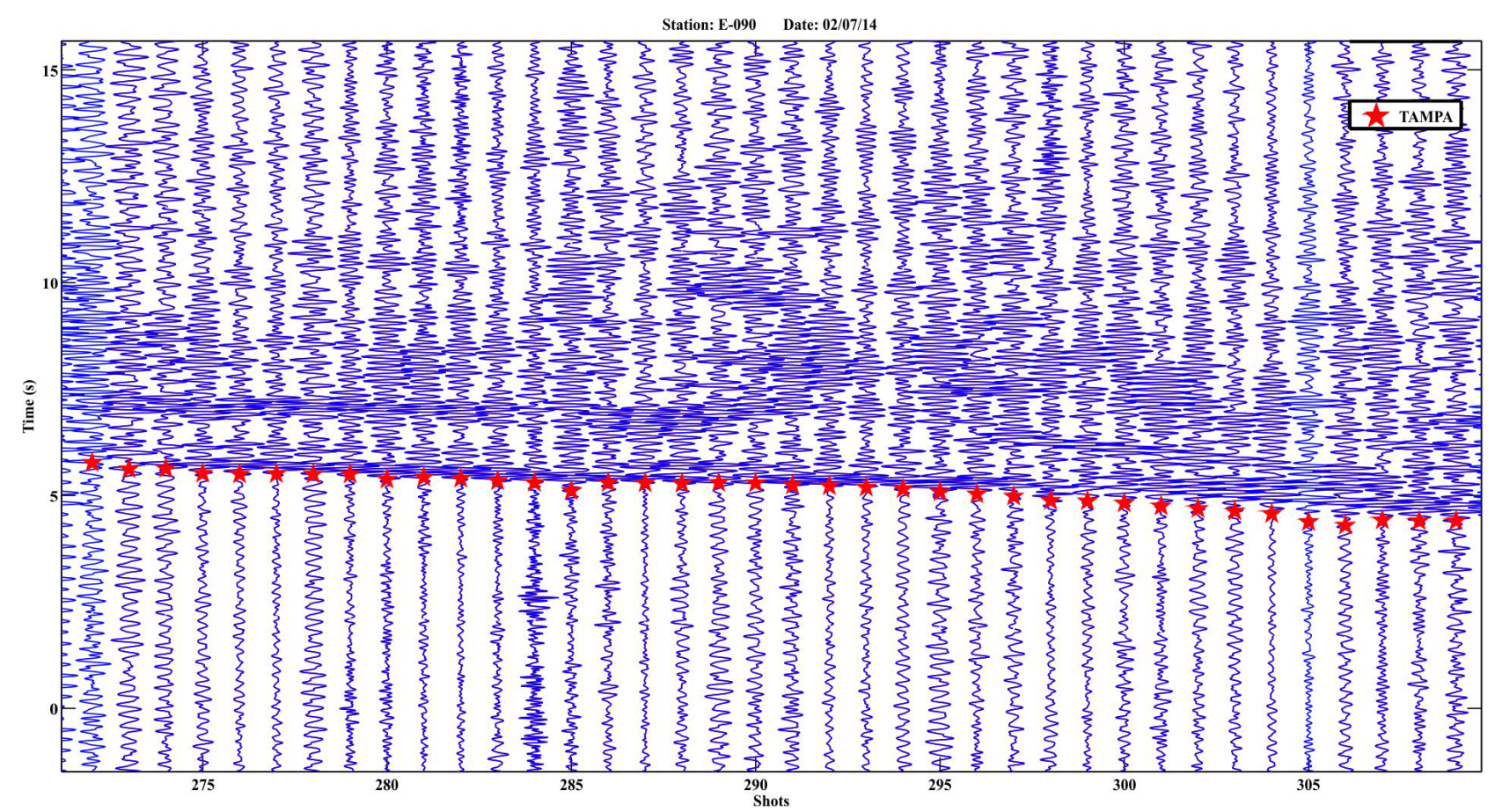

Figure 21. An example of different correlative shots recorded in a single short-period portable station. (Date format: $\mathrm{dd} / \mathrm{mm} / \mathrm{yy}$ ). 
a)
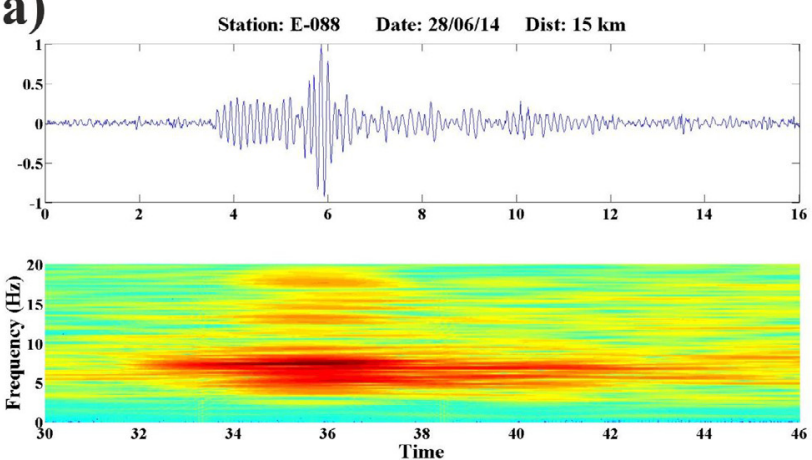

c)
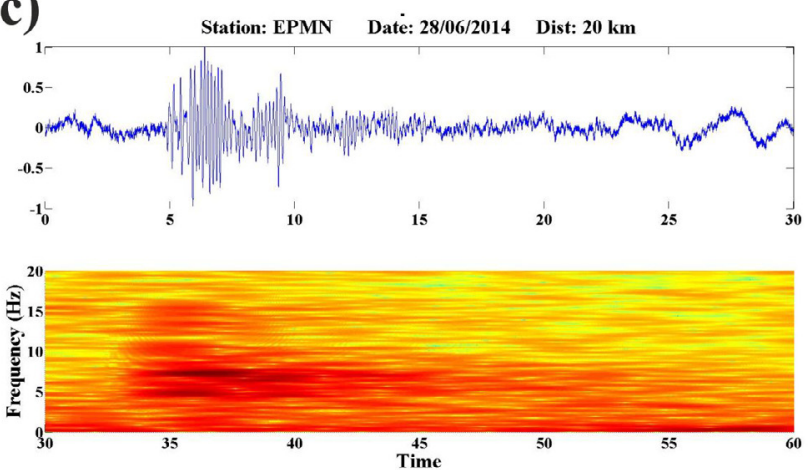

b)
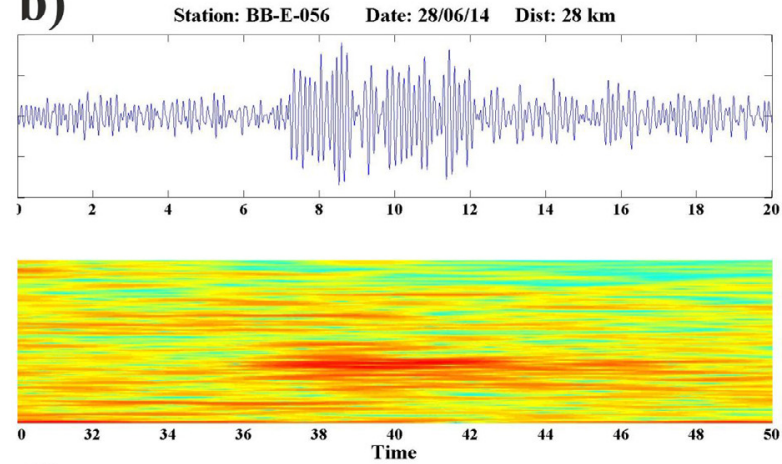

d)
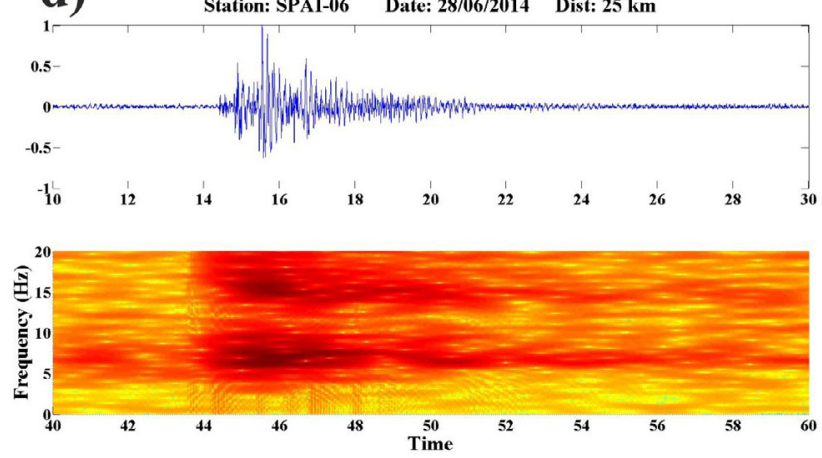

Figure 22. Examples of a shot recorded in different seismic stations, short-period, broadband, OBSs and permanent station of the INGV. (Date format: $\mathrm{dd} / \mathrm{mm} / \mathrm{yyyy}$ ).

\section{Final remarks}

As reported in the present manuscript, probably the TOMO-ETNA experiment is the most complex experiment focused to obtain information on the inner structure of an active volcano and surrounding areas using both active and passive seismic sources. The efficiency and coordination in the performed work has allowed deploying in a short time a large number of seismic stations. All of them were operative along the scheduled time, safely recovered, and even if the island if Sicily is a very populated region, no seismic station was damaged. The first step in the success of this deployment was based on an efficient search of potential sites a few months before the arrival of the working team, including complete and detailed information on the characteristics of the sites, owners, contacts and easy indications of how to arrive to them. The final document generated in this search is very valuable information that could be used in the future for new experiments. The second factor contributing to the success was the division into several teams responsible of the deployment and the maintenance of the seismic stations distributed in different sectors covering the whole region under study. These teams were autonomous and, following the indications of the provided documents, were able to design an efficient daily working program, coordinated by a single person who was responsible for any final decision. It is remarkable the high quality, portability and feasibility of the used instruments, in particular the Cube shortperiod seismic stations are ideal to be used in this kind of experiments. The quality of the recorded data predicts final results that could have a high impact in the scientific community.

Acknowledgements. This paper has been partially funded by the following research projects: the European project MED-SUV funded by the European Union's Seventh Framework Program for research, technological development and demonstration under grant agreement No. 308665; the Spanish COCSABO project (COC-DI-2011-08); the European project EUROFLEETS2 (Seventh Framework Programme, grant agreement No. 312762) through transnational access to the research vessels "Sarmiento de Gamboa", operated by CSIC (Spain), and "Aegaeo", by HCMR (Greece); the Geophysical Instrument Pool Potsdam (GIPP) from GFZ (Potsdam) with the project (Seismic TOMOgraphy of ETNA volcano and Eolian Islands, Italy, using active and passive seismic data). We would like to thank the following supporting institutions: Dipartimento Regionale della Protezione Civile, Regione Siciliana; Dipartimento Azienda Regionale Foreste Demaniali, Ufficio Provinciale di Catania; Ente Parco dell'Etna; Unidad de Tecnología Marina - CSIC in Barcelona (Spain); Stato Maggiore Marina (Italian Navy General Staff), CINCNAV (Command in Chief of the Fleet) and Marisicilia (Navy Command of Sicily); Coastal Guard of Messina and Riposto; to obtain support and navigation permissions for the oceanographic cruises: Spanish Foreign Office and Italian Foreign Office. This paper has been partially supported by the Spanish projects TEC201568752-R (MINECO/FEDER), KNOWAVES and CGL2015-67130C2-2. We would like to thank all private and public owners of the sites selected to deploy seismic stations for their kind and unselfish disposal to use their properties. This manuscript has been largely improved by the insightful comments of Dr. Simona Petrosino and an anonymous reviewer and by the editor José Morales. 


\section{References}

Álvarez, I., García, L., Mota, S., Cortés, G., Benítez, C., and De la Torre, A. (2013). An automatic P-Phase picking algorithm base on adaptive multiband processing, Geoscience and Remote Sensing Letters, 10, 1488-1492.

Aoki, Y., et al. (2009). P wave velocity structure beneath Asama volcano, Japan, inferred from active source seismic experiment, Journal of Volcanology and Geothermal Research, 187(3/4), 272-277, doi:10.1016/ j.jvolgeores.2009.09.004.

Barberi, G., Giampiccolo, E., Musumeci, C., Scarfi, L., Bruno, V., Cocina, O., Díaz-Moreno, A., Sicali, S., Tusa, G., Tuvè, T., Zuccarello, L., Ibáñez, J.M., and Patanè, D. (2016). Seismic and volcanic activity during 2014 in the region involved by TOMO-ETNA seismic active experiment, Annals of Geophysics, 59(4), S0429, doi:10.4401/ag-7082.

Barclay, A.H., Wilcock, W.S.D., and Ibáñez, J.M. (2009). Bathymetric constraints on the tectonic and volcanic evolution of Deception Island Volcano, South Shetland Islands, Antarctic Science, 21(2), 153-167.

Battaglia, J., Zollo, A., Virieux, J., and Dello Iacono, D. (2008). Merging active and passive data sets in traveltime tomography: the case study of Campi Flegrei caldera (Southern Italy), Geophysical Prospecting, 56(4), 555-573.

Ben-Zvi, T., Wilcock, W.S., Barclay, A.H., Zandomeneghi, D., Ibáñez, J.M., and Almendros, J. (2009). The P-wave velocity structure of Deception Island, Antarctica, from two-dimensional seismic tomography, Journal of Volcanology and Geothermal Research, 180(1), 67-80.

Carmona, E., Almendros, J., Serrano, I., Stich, D., and Ibáñez, J.M. (2012). Results of seismic monitoring surveys of Deception Island volcano, Antarctica, from 1999-2011, Antarctic Science, 24(5), 485-499.

Cassinis, R, I. Finetti, P. Giese, C. Morelli, L. Steinmetz, and O. Vecchia, (1969). Deep seismic refraction research on Sicily, Bollettino di Geofisica Teorica e Applicata, 11, 140-160.

Castellano, M., et al. (2008). Seismic tomography experiment at Italy’s Stromboli Volcano, Eos - Transactions American Geophysical Union, 89(30), 269-270.

Cavallaro, D., Cocchi, L., Coltelli, M., Muccini, F., Carmisciano, C., Firetto Carlino, M., Ibáñez, J.M., Patanè, D., Filippone, M., and Buttaro, E. (2016). Acquisition procedures, processing methodologies and preliminary results of magnetic and ROV data collected during the TOMO-ETNA experiment, Annals of Geophysics, 59(4), S0431, doi:10.4401/ag-7084.

Chouet, B.A. (1996). New methods and future trends in seismological volcano monitoring, In: Monitor- ing and mitigation of volcano hazards, Springer, Berlin/Heidelberg, 23-97.

Chouet, B. (2003). Volcano seismology, Pure and Applied Geophysics, 160(3/4), 739-788.

Chouet, B.A., and Matoza, R.S. (2013). A multi-decadal view of seismic methods for detecting precursors of magma movement and eruption, Journal of Volcanology and Geothermal Research, 252, 108-175.

Colombi, B., Guerra I., Luongo, G., and Scarascia, S. (1979). Profilo sismico a rifrazione Acireale-Termini Imerese, Atti del Conv. P. F. Geodinamica, 235, 155170.

Coltelli, M., et al. (2016). The marine activities performed within the TOMO-ETNA experiment, Annals of Geophysics, 59(4), S0428, doi:10.4401/ag-7081.

De Barros, L., Martini, F., Bean, C.J., Garcia-Yeguas, A., and Ibáñez, J.M. (2012). Imaging magma storage below Teide volcano (Tenerife) using scattered seismic wavefields, Geophysical Journal International, 191(2), 695-706.

De Siena, L., Del Pezzo, E., and Bianco, F. (2010). Seismic attenuation imaging of Campi Flegrei: Evidence of gas reservoirs, hydrothermal basins, and feeding systems, Journal of Geophysical Research: Solid Earth (1978-2012), 115(B9).

De Siena, L., Del Pezzo, E., and Bianco, F. (2011). A scattering image of Campi Flegrei from the autocorrelation functions of velocity tomograms, Geophysical Journal International, 184(3), 1304-1310.

Di Stefano, R., and Chiarabba, C. (2002). Active source tomography at Mt. Vesuvius: constraints for the magmatic system, Journal of Geophysical Research: Solid Earth (1978-2012), 107(B11), ESE-4.

Díaz-Moreno, A., Koulakov, I., García-Yeguas, A., Jakovlev, A., Barberi, G., Cocina, O., Zuccarello, L., Scarfi, L., Patanè, D., Álvarez, I., García, L., Benítez, C., Prudencio, J., and Ibáñez, J.M. (2016). PARTOS - Passive and Active Ray TOmography Software: description and preliminary analysis using TOMOETNA experiment's dataset, Annals of Geophysics, 59(4), S0435, doi:10.4401/ag-7088.

Firetto Carlino, M., Zgur, F., Bruno, P.P.G., Coltelli, M., Sormani, L., Cavallaro, D., Ibáñez, J.M., and Patanè, D. (2016). Acquisition and preliminary analysis of multi-channel seismic reflection data, acquired during the oceanographic cruises of the TOMO-ETNA experiment, Annals of Geophysics, 59(4), S0430, doi:10.4401/ag-7083.

García-Yeguas, A., Almendros, J., Abella, R., and Ibáñez, J.M. (2011). Quantitative analysis of seismic wave propagation anomalies in azimuth and apparent slowness at Deception Island volcano (Antarctica) using seismic arrays, Geophysical Journal Interna- 
tional, 184(2), 801-815

García-Yeguas, A., Koulakov, I., Ibáñez, J.M., and Rietbrock, A. (2012). First high resolution P wave velocity structure beneath Tenerife Island (Canary Islands, Spain), Journal of Geophysical Research, doi:10.102 9/2011JB008970.

García, L., Álvarez, I., Benítez, C., Titos, M., Bueno, M., Mota, S., de la Torre, Á., Segura, J.C., Alguacil, G., Díaz-Moreno, A., Prudencio, J., García-Yeguas, A., Ibáñez, J.M., Zuccarello, L., Cocina, O., and Patanè, D. (2016). Advances on the automatic estimation of the P-wave onset time, Annals of Geophysics, 59(4), S0434, doi:10.4401/ag-7087.

Gasparini, P. (1998). Looking inside Mt. Vesuvius, Eos - Transactions American Geophysical Union, 79(19), 229-232.

Hirn, A., Nicolich, R., Gallart, J., Laigle, M., Cernobori, L., and ETNASEIS Scientific Group (1997). Roots of Etna volcano in faults of great earthquakes, Earth and Planetary Science Letters, 148, 171-191.

Ibáñez, J.M., Rietbock, A., and García-Yeguas, A. (2008). Imaging an active volcano edifice at Tenerife Island, Spain, Eos - Transactions American Geophysical Union, 89(32), 289-290.

Ibáñez, J.M., Prudencio, J., Díaz-Moreno, A., Patanè, D., Puglisi, G., Lühr, B.-G., Carrión, F., Dañobeitia, J.J., Coltelli, M., Bianco, F., Del Pezzo, E., Dahm, T., Willmott, V., and Mazauric, V. (2016). The TOMOETNA experiment: an imaging active campaign at Mt. Etna volcano. Context, main objectives, working-plans and involved research projects, Annals of Geophysics, 59(4), S0426, doi:10.4401/ag-7079.

Jolly, A.D., Lokmer, I., Kennedy, B., Keys, H.J.R., Proctor, J., Lyons, J.J., and Jolly, G.E. (2014). Active seismic sources as a proxy for seismic surface processes: An example from the 2012 Tongariro volcanic eruptions, New Zealand, Journal of Volcanology and Geothermal Research, 286, 317-330.

Judenherc, S., and Zollo, A. (2004). The Bay of Naples (southern Italy): Constraints on the volcanic structures inferred from a dense seismic survey, Journal of Geophysical Research: Solid Earth (1978-2012), 109(B10).

Kiser, E., Levander, A., Harder, S., Abers, G., Creager, K., Vidale, J.E., Moran, S.C., and Malone, S.D. (2013). iMUSH: The design of the Mount St. Helens highresolution active source seismic experiment, In: EGU General Assembly Conference Abstracts, 15, 12325.

Koulakov, I., and Shapiro, N.M. (2015). Seismic tomography of volcanoes, In: M. Beer, I.A. Kougioumtzoglou, E. Patelli and A. Siu-Kui (eds.), Encyclopedia of Earthquake Engineering, Springer, Berlin/Heidelberg, 3117-3134, ISBN:978-3-642-35343-7, doi:10.
1007/978-3-642-35344-4_51.

Lees, J.M. (2007). Seismic tomography of magmatic systems, Journal of Volcanology and Geothermal Research, 167(1), 37-56.

Levander, A., Kiser, E., Palomeras, I., Zelt, C., Schmandt, B., Hansen, S., Harder, S., Creagar, K., Vidale, J., and Abers, G. (2015). Preliminary Results from the iMUSH Active Source Seismic Experiment, In EGU General Assembly Conference Abstracts, 17, 7550.

Lodge, A., Nippress, S.E.J., Rietbrock, A., García-Yeguas, A., and Ibáñez, J.M. (2012). Evidence for magmatic underplating and partial melt beneath the Canary Islands derived using teleseismic receiver functions, Physics of the Earth and Planetary Interiors, 212, 44-54.

Maercklin, N., Riedel, C., Rabbel, W., Wegler, U., Lühr, B.G., and Zschau, J. (2000). Structural investigation of Mt. Merapi by an active seismic experiment, Mitteilungen/Deutsche Geophysikalische Gesellschaft, 4, 13-16.

Marsella, E., et al. (2007). The Stromboli geophysical experiment. Preliminary report on wide angle refraction seismics and morphobathymetry of Stromboli island (Southern Tyrrhenian sea, Italy) based on integrated offshore-onshore data acquisition (cruise STRO-06 R/V Urania), Technical Report, CNR ISMAR, Bologna.

McNutt, S.R. (2002). Volcano seismology and monitoring for eruptions, International Geophysics Series, 81(A), 383-406.

McNutt, S.R. (2005). Volcanic seismology, Annual Review of Earth and Planetary Sciences, 32, 461-491.

Nicolich, R., Laigle, M., Hirn, A., Cernobori, L., and Gallart, J. (2000). Crustal structure of the Ionian margin of Sicily: Etna volcano in the frame of regional evolution, Tectonophysics, 329(1), 121-139.

Nishimura, T., N. Uchida, H. Sato, M. Ohtake, S. Tanaka, and H. Hamaguchi, (2000). Temporal changes of the crustal structure associated with the M6.1 earthquake on September 3, 1998, and the volcanic activity of Mount Iwate, Japan, Geophysical Research Letters, 27, 269-272.

Nishimura, T., Tanaka, S., Yamawaki, T., Yamamoto, H., Sano, T., Sato, M., Nakahara, H., Uchida, N., Hori, S., and Sato, H. (2005). Temporal changes in seismic velocity of the crust around Iwate volcano, Japan, as inferred from analyses of repeated active seismic experiment data from 1998 to 2003, Earth, Planets and Space, 57(6), 491-505.

Onizawa, S.Y., et al. (2007). P-wave velocity structure of Usu volcano: Implication of structural controls on magma movements and eruption locations, Journal of Volcanology and Geothermal Research, 160(1), 
175-194.

Paulatto, M., et al. (2010). Upper crustal structure of an active volcano from refraction/reflection tomography, Montserrat, Lesser Antilles, Geophysical Journal International, 180(2), 685-696.

Prudencio, J., Del Pezzo, E., García-Yeguas, A., and Ibáñez, J.M. (2013a). Spatial distribution of intrinsic and scattering seismic attenuation in active volcanic islands - I: model and the case of Tenerife Island, Geophysical Journal International, 195(3), 19421956, doi:10.1093/gji/ggt361.

Prudencio, J., Ibáñez, J.M., García-Yeguas, A., Del Pezzo, E., and Posadas, A.M. (2013b). Spatial distribution of intrinsic and scattering seismic attenuation in active volcanic islands - II: Deception Island images, Geophysical Journal International, 195(3), 1957-1969, doi:10.1093/ gji / ggt360.

Prudencio, J., De Siena, L., Ibáñez, J.M., Del Pezzo, E., García-Yeguas, A., and Díaz-Moreno, A. (2015a). The 3D Attenuation Structure of Deception Island (Antarctica), Surveys in Geophysics, 36(3), 371-390.

Prudencio, J., Del Pezzo, E., Ibáñez, J.M., Giampiccolo, E., and Patanè, D. (2015b). Two-dimensional seismic attenuation images of Stromboli Island using active data, Geophysical Research Letters, 42(6), 1717-1724.

Prudencio, J., Ibáñez, J.M., Del Pezzo, E., Martí, J., García-Yeguas, A., and De Siena, L. (2015c). 3D Attenuation Tomography of the Volcanic Island of Tenerife (Canary Islands), Surveys in Geophysics, 36(5), 693716.

Shalev, E., Kenedi, C.L., Malin, P., Voight, V., Miller, V., Hidayat, D., Sparks, R.S. J., Minshull, T., Paulatto, M., Brown, L., and Mattioli, G. (2010). Three-dimensional seismic velocity tomography of Montserrat from the SEA-CALIPSO offshore/onshore experiment, Geophysical Research Letters, 37(19).

Tanaka, S., et al. (2002). Three-dimensional P-wave velocity structure of Iwate volcano, Japan from active seismic survey, Geophysical Research Letters, 29(10), 59-1.

Tomatsu, T., Kumagai, H., and Dawson, P.B. (2001). Tomographic inversion of $\mathrm{P}$-wave velocity and $\mathrm{Q}$ structures beneath the Kirishima volcanic complex, southern Japan, based on finite difference calculations of complex traveltimes, Geophysical Journal International, 146(3), 781-794.

Vanorio, T., Virieux, J., Capuano, P., and Russo, G. (2005). Three-dimensional seismic tomography from $\mathrm{P}$ wave and $\mathrm{S}$ wave microearthquake travel times and rock physics characterization of the Campi Flegrei Caldera, Journal of Geophysical Research: Solid Earth (1978-2012), 110(B3).
Voight, B., et al. (2014). The SEA-CALIPSO volcano imaging experiment at Montserrat: plans, campaigns at sea and on land, scientific results, and lessons learned, Geological Society, London, Memoirs, 39(1), 253289.

Wassermann, J. (2002). Volcano seismology, IASPEI New Manual of Seismological Observatory Practice, 1(13), 662-703.

Wegler, U., Lühr, B.G., and Ratdomopurbo, A. (1999). A repeatable seismic source for tomography at volcanoes, Annali di Geofisica, 42(3), 565-571.

Wegler, U., and Lühr, B.G. (2001). Scattering behaviour at Merapi volcano (Java) revealed from an active seismic experiment, Geophysical Journal International, 145(3), 579-592.

Yamamoto, M., and Sato, H. (2010). Multiple scattering and mode conversion revealed by an active seismic experiment at Asama volcano, Japan, Journal of Geophysical Research: Solid Earth (1978-2012), 115(B7).

Yamawaki, T., et al. (2004). Three-dimensional P-wave velocity structure of Bandai volcano in northeastern Japan inferred from active seismic survey, Journal of Volcanology and Geothermal Research, 138(3), 267-282.

Zandomeneghi, D., Barclay, A., Almendros, J., Ibañez Godoy, J.M., Wilcock, W.S., and Ben-Zvi, T. (2009). Crustal structure of Deception Island volcano from $\mathrm{P}$ wave seismic tomography: Tectonic and volcanic implications, Journal of Geophysical Research: Solid Earth (1978-2012), 114(B6).

Zandomeneghi, D., Kyle, P., Miller, P., Passcal, I., Snelson, C., and Aster, R. (2010). Seismic Tomography of Erebus Volcano, Antarctica. Eos - Transactions American Geophysical Union, 91(6), 53-55.

Zandomeneghi, D., Aster, R., Kyle, P., Barclay, A., Chaput, J., and Knox, H. (2013). Internal structure of Erebus volcano, Antarctica imaged by high-resolution active-source seismic tomography and coda interferometry, Journal of Geophysical Research: Solid Earth, 118(3), 1067-1078.

Zobin, V.M. (2011). Introduction to volcanic seismology, Elsevier.

Zollo, A., et al. (1996). 2D seismic tomography of Somma-Vesuvius. Description of the experiment and preliminary results, Annali di Geofisica, 39(3), 471-486.

Zollo, A., et al. (1998). An image of Mt. Vesuvius obtained by 2D seismic tomography, Journal of Volcanology and Geothermal Research, 82(1), 161-173.

Zollo, A., D’Auria, L., De Matteis, R., Herrero, A., Virieux, J., and Gasparini, P. (2002). Bayesian estimation of 2-D P-velocity models from active seismic arrival time data: imaging of the shallow structure of 
Mt. Vesuvius (Southern Italy), Geophysical Journal International, 151(2), 566-582.

Zollo, A., Judenherc, S., Auger, E., D’Auria, L., Virieux, J., Capuano, P., Chiarabba, C., de Franco, R., Makris, J., Michelini, A., and Musacchio, G. (2003). Evidence for the buried rim of Campi Flegrei caldera from 3-d active seismic imaging, Geophysical Research Letters, 30(19).

Zschau, J., Sukhyar, R., Purbawinata, M.A., Lühr, B.-G., and Westerhaus, M. (1998). Project MERAPI - interdisciplinary research at a high-risk volcano, In: J. Zschau and M. Westerhaus (eds.), Decade-Volcanoes under Investigation, Mitteilungen/Deutsche Geophysikalische Gesellschaft, 3, 3-8.

Zuccarello, L., Paratore, M., La Rocca, M., Ferrari, F., Messina, A., Branca, S., Contrafatto, D., Galluzzo, D., Rapisarda, S., and García, L. (2016). Shallow velocity model in the area of Pozzo Pitarrone, Mt. Etna, from single station, array methods and borehole data, Annals of Geophysics, 59(4), S0433, doi:10.44 01/ag-7086.

*Corresponding author: Jesús M. Ibáñez, Instituto Andaluz de Geofisica, Universidad de Granada, Granada, Spain; email: jibanez@ugr.es. 